\title{
Sistemas de Resolución Alternativa de Conflictos (ADR) en derecho tributario español y comparado. Propuestas para Latinoamérica y España**
}

\section{Alternative Dispute Resolution (ADR) in Spanish and Comparative Tax Law. Proposal for Latin America and Spain}

\section{RESUMEN}

En línea con la opinión del Departamento de Derechos de los Ciudadanos y Asuntos Constitucionales del Parlamento Europeo (2014), en este artículo se aboga por la inclusión de los sistemas alternativos de resolución de conflictos (ADR) como sistemas absolutamente cooperantes a la reducción de la litigiosidad en aquellos países como España y muchos Estados de Latinoamérica donde desafortunadamente la litigiosidad tributaria es un hecho de difícil erradicación. Tras ser analizados los principales referentes mundiales internacionales de ADR en derecho tributario comparado legisla-

* Catedrática de Derecho Tributario (acreditada), Universidad de Barcelona. Licenciada en Derecho (Premio extraordinario de licenciatura N. 1 promoción); doctora en Derecho (Premio extraordinario de Doctorado); licenciada en Ciencias Económicas y Empresariales; directora de Education and Law Review; Premio de la AEDAF; Premio del CEF; investigadora principal y miembro de multitud de proyectos de investigación nacional e internacional. Visiting scholar en Harvard School of Law, European University Institute, Università di Roma 'La Sapienza', Università degli Studi di Firenze, IBDF (Ámsterdam), LSE of London, University of Leeds (UK). Autora de más de cien publicaciones. También ha ocupado cargos de gerencia en la Universidad de Barcelona. Contacto: eandres@ub.edu

** El presente trabajo se enmarca en el Proyecto de Investigación DER 2015-68768-P Resolución de controversias fiscales "transnacionales" y cooperación administrativa internacional. Rasgos de una arquitectura institucional desde una perspectiva europea. Ministerio de Economía y Competitividad 2016-2020 (Investigadora Principal: E Andrés Aucejo. siendo fruto de los quince últimos años de investigación por parte de su autora quien ha publicado un número ingente de artículos científicos indexados y capítulos de libro en la materia, siendo Investigadora principal de dos proyectos específicos al respecto financiados por la Presidencia del Generalidad de Cataluña y por el Ministerio de España.

Recibido el 20 de junio de 2016, aprobado el 1. ${ }^{\circ}$ de octubre de 2016.

Para citar el artículo: AndRÉs AucEJo, E. Sistemas de Resolución Alternativa de Conflictos (ADR) en derecho tributario español y comparado. Propuestas para Latinoamérica y España. Derecho del Estado n. ${ }^{\circ}$ 37, Universidad Externado de Colombia, julio-diciembre de 2016, pp. 3-68. Dor: http://dx.doi.org/10.18601/01229893.n37.01 
dos en Estados Unidos, Alemania, Francia, Reino Unido, Italia, Holanda, Suecia y otros países, este artículo realiza una propuesta de política fiscal para su aplicación en España y Latinoamérica, consistente en legislar tres paquetes de medida de ADR arbitrables en los tres estadios siguientes: a) con antelación a la fase administrativa, b) en la fase administrativa, c) en la fase contencioso administrativa.

PALABRAS CLAVE

Resolución alternativa de conflictos, mediación, arbitraje, conciliación judicial, acuerdos administrativos, estadísticas en litigios tributarios, actas con acuerdo de la Administración, Defensor del Contribuyente.

ABSTRACT

The author of this article is in favor of the inclusion of Alternative Dispute Resolution (ADR) systems in tax matters in Spain and in many States of Latin America where the tax litigation is unfortunately a difficult fact to eradicate. The main ADR systems legislated in comparative tax law (US, Germany, France, Britain, Italy, the Netherlands, Sweden and other countries) are analyzed. Finally, the paper contains a proposal to be applicable in Spain and Latin America consisting of legislating three packages of measures to implement ADR in tax matters in the following three stages. Namely: a) prior to the administrative phase, b) administrative phase, c) in judicial phase.

\section{KEYWORDS}

Alternative Dispute Resolution, mediation, arbritration, conciliation, administrative agreements, statistics in tax litigation, proceedings with the agreement of the Administration, taxpayer advocate.

SUMARIO

1. Introducción. 2. Estadísticas en materia de litigiosidad tributaria en España. 3. Regulación vigente en derecho tributario español. La orfandad de Sistemas Alternativos de Resolución de Conflictos (ADR). 3.1. Técnicas de prevención del litigio en la fase de iniciación del procedimiento de gestión (autoliquidación del tributo).3.2. Sistemas convencionales de terminación de litigios en el procedimiento de liquidación.3.3. Alternativas convencionales en fase de recaudación y revisión. 3.4. Informes preparatorios de los Comités de Expertos de los trabajos preparatorios de la Ley General Tributaria. 3.5. El anteproyecto de modificación parcial de la Ley 58/2003, de 17 de diciembre, General Tributaria. 4. Referentes internacionales. Sistemas de ADR en dere- 
cho tributario comparado (estudio por fases de los sistemas de prevención de litigios; sistemas de ADR en vía administrativa y sistemas de ADR en vía contenciosa; cuadros sinópticos). 4.1. Estados Unidos: modelo por excelencia en ADR. 4.2. Europa. 4.2.1. Italia: referente de la UE. 4.2.2. Francia. 4.2.3. Alemania. 4.2.4. Reino Unido. 4.2.5. Suecia. 4.2.6. Holanda. 4.3. Australia. 4.4. Latinoamérica. Chile y Colombia. 5. Propuestas de política fiscal sobre ADR en materia tributaria aplicables en los ordenamientos tributarios latinoamericanos y España. 5.1. Modelo de mediación tributaria aplicable en los ordenamientos latinoamericanos. 5.2. Sobre la necesidad de legislar sistemas de ADR. 5.3. Las consultas a la Administración. 5.4. La revocación de los actos administrativos tributarios contrarios al contribuyente. 5.5. The Taxpayers' Advocate . 5.6. Los acuerdos en vía administrativa tributaria. 6. La conveniencia de las técnicas transaccionales en vía de la jurisdicción contencioso administrativa.

\section{INTRODUCCIÓN}

Es un hecho constatable en España y Latinoamérica la existencia de altas tasas de conflictividad en materia tributaria, como lo pone de manifiesto la situación en la que se encuentran los órganos revisores tanto administrativos como jurisdiccionales en materia tributaria.

Para combatir los colapsos que sufren los órganos revisores, mayores asignaciones de medios materiales y humanos devienen insuficientes. En línea con lo sucedido en las principales democracias occidentales del mundo, los sistemas de "Resolución Alternativa de Conflictos" (en adelante, ADR) aplicados a la materia tributaria constituyen un factor clave de importancia crucial en la lucha contra la litigiosidad.

El profundo convencimiento de la relevancia del problema que representan elevadas tasas de litigiosidad tributaria fue -precisamente- una de las razones principales que movió al legislador italiano a consolidar institutos jurídicos de naturaleza tributaria con fines concordatarios o conciliativos. Los resultados experimentados han sido extraordinarios en términos de reducción de la litigiosidad, disminución de costes y mejora de la justicia tributaria ${ }^{1}$.

Hoy, muchos años después de que estudiara dicho fenómeno, el Parlamento Europeo (Departamento de Derechos de los Ciudadanos y Asuntos Consti-

1 Andrés AucEJo, E. Evaluación de la litigiosidad en el "Rapporto tributario" en Italia. Rivista di Diritto tributario internazionale (International Tax Law Review), n. ${ }^{\circ}$ 2, 2002, 244-278; Íd. L'evoluzione della litigiosità nelle "commissioni tributarie" italiane nel corso degli anni 1990-2000. Diritto e pratica tributaria, n. ${ }^{\circ}$ 4/2004; Íd., La resolución alternativa de conflictos tributarios en Italia. Madrid: IEF, 2009. Ver Íd. Reclamo e mediazione tributaria nel Diritto tributario italiano. ¿Para cuándo en España? Quincena Fiscal, n. ${ }^{\circ}$ 17, 2014. 
tucionales, siguiendo la opinión de 816 expertos) se ha mostrado proclive a sistemas alternativos como la mediación, encumbrando como prototipo de modelo a seguir, precisamente, el italiano, en el que se ha optado por la mediación obligatoria en el proceso civil, lo que ha generado resultados positivos, y donde a partir del año 2010 también se opta por el reclamo y mediación obligatoria antes de incoar la jurisdicción tributaria para resolver asuntos de pequeña cuantía, pero que en la práctica de los tribunales tributarios representan el $85 \%$ del volumen de trabajo ${ }^{2}$.

Este hecho es igualmente constatable en otros ordenamientos jurídicos de democracias occidentales, donde cada vez se incrementa más el número de sistemas de ADR en materia tributaria como mecanismo para reducir la litgiosidad, disminuir costes y agilizar la resolución de los litigios.

Estados Unidos sin duda es el paradigma. Allí, progresivamente se ha ido legislando y reglamentando toda una batería de sistemas cada vez mayor de mecanismos alternativos en vía tributaria, pudiendo observarse pautas de dicho ensanchamiento y legislación progresiva en materia de ADR en Reino Unido, Australia y Holanda, por ejemplo, como tendremos oportunidad de analizar en epígrafes siguientes.

Lamentablemente los modelos occidentales avanzados no parecen tener cabida en España ni en la mayoría de países de Latinoamérica.

Por lo que respecta al panorama nacional, cualificados votos particulares de altas instancias de la Agencia Estatal de la Administración tributaria Española -desde hace años y también en el momento presente- manifiestan su reticencia hacia los sistemas de ADR alegando que se trata de sistemas de "toma y daca" o "mercadeo", y esto cuando no justifican su rechazo de estos métodos en aras de los tan manidos principios de legalidad tributaria e indisponibilidad del crédito tributario. Y nada más alejado de la realidad jurídica.

Hasta el momento pues, tal y como llevo denunciando en publicaciones y congresos internacionales desde hace más de quince años, en España no existe una verdadera y generalizada concienciación sobre los problemas que plantean índices de litigiosidad elevados y, lo que es más importante, sobre en qué se concreta tal litigiosidad, que lamentablemente en la materia tributaria afecta a todos los estratos: administrativo, económico-administrativo y contencioso administrativo. De ahí precisamente lo llamativo y grave. El hecho es bien conocido y, sin embargo, hasta el momento no se ha llegado a acometer auténticos sistemas de ADR en materia tributaria para mejorar la situación, en línea con lo que sucede en las democracias más avanzadas del mundo.

2 "Rebooting the Mediation Directive: Assessing the limited impact of its implementation and proposing measures to increase the number of mediations in the UE", 2014. 


\section{ESTADÍSTICAS EN MATERIA DE LITIGIOSIDAD TRIBUTARIA EN ESPAÑA}

Infortunadamente asistimos a un problema, hoy crónico, en materia de litigiosidad tributaria en vía económico administrativa.

\section{A. Primer intervalo de referencia: de 1998 a 2002[3]}

Análisis de los datos estadísticos del conjunto de los tribunales económico administrativos regionales y locales (TEARS y TEALS): series temporales sobre la evolución de la litigiosidad y tasas indicativas del volumen de trabajo y capacidad de resolución.

Tabla 8. Datos estadísticos del conjunto de los TEARs y los TeaLs

\begin{tabular}{lcccccc}
\hline \multicolumn{1}{c}{ Año } & 1998 & 1999 & 2000 & 2001 & 2002 & Promedio \\
\hline $\begin{array}{l}\text { Pendientes } \\
\text { Inicio }\end{array}$ & 235310 & 235845 & 215698 & 215854 & 236505 & 227842 \\
Ingresados & 161291 & 144588 & 149342 & 167716 & 126688 & 149925 \\
$\begin{array}{l}\text { Totales (ingresados + } \\
\text { pend. ini.) }\end{array}$ & 396601 & 380433 & 365040 & 383570 & 363193 & 377767 \\
$\begin{array}{l}\text { Resueltos } \\
\begin{array}{l}\text { Pendientes } \\
\text { fin año }\end{array}\end{array}$ & 160756 & 164735 & 149186 & 147065 & 129486 & 150246 \\
$\begin{array}{l}\text { Estimadas } \\
\text { total + parcial }\end{array}$ & 235845 & 215698 & 215854 & 236505 & 233707 & 227522 \\
$\begin{array}{l}\text { Desestimadas } \\
\text { y otros }\end{array}$ & 64319 & 59983 & 57827 & 55360 & 52978 & 58093 \\
\hline $\begin{array}{l}\text { Velocidad de } \\
\text { resolución }\end{array}$ & 82455 & 104752 & 91364 & 91727 & 96287 & \\
$\begin{array}{l}\text { Tasa eficacia } \\
\text { Tasa de resolución }\end{array}$ & 2,5 & 2,3 & 2,4 & 2,6 & 2,8 & 2,48 \\
\hline
\end{tabular}

Fuente: elaboración propia, a partir de los datos extraídos de las Memorias Tributarias de la AEAT (www.aeat.es).

3 Andrés Aucejo, E. y Royuela Mora, V. Análisis estadístico de la litigiosidad en los tribunales económico administrativos regionales, locales y el Tribunal Económico Administrativo Central. Quinquenio: 1998-2002. En Revista Crónica Tributaria , n. ${ }^{\circ} 115,2005,0210-2919$; M. 12.580 - 1961, disponible on line en Documentos del Instituto de Estudios Fiscales, Doc. n. ${ }^{\circ}$ 25/04. ISSN:1578-0244. 
Gráfico 10. Evolución del conjunto de los TEARs y los TEALS

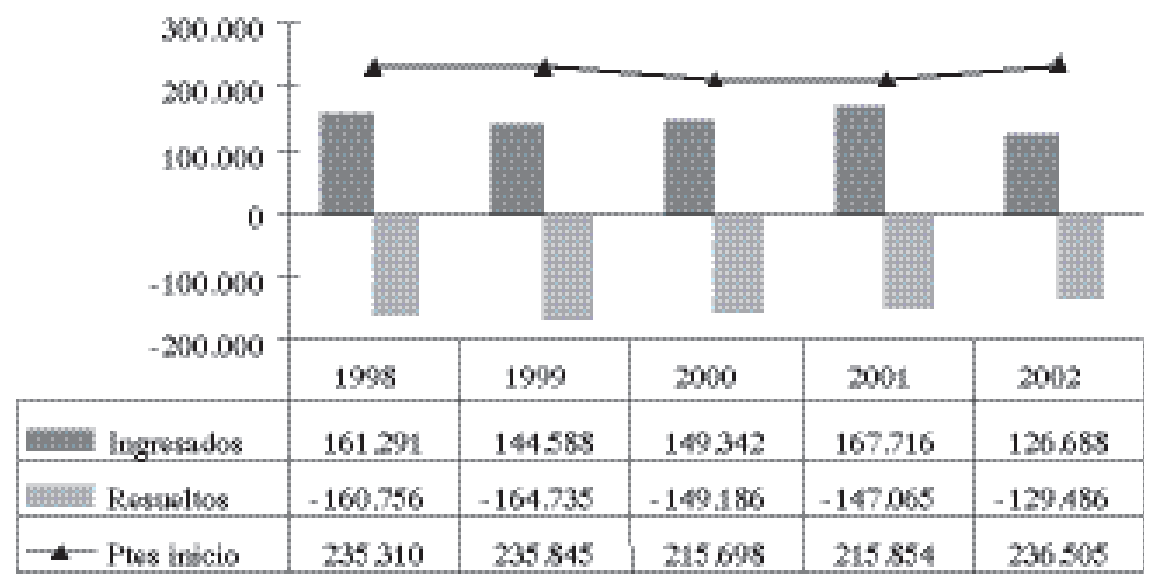

Al inicio del año 1998 ya existía un volumen de expedientes pendientes de resolver en el conjunto de tribunales regionales y locales de 235.310, cuantía que infortunadamente no ha disminuido en el quinquenio de referencia, habida cuenta del hecho de que en el año 2002 restaban pendientes de resolver 236.505 expedientes al inicio del ejercicio (unos 1.200 expedientes más que cinco años antes). Estos malos resultados no se deben a que haya incrementado el número de expedientes que ingresan, sino a que el número total de expedientes resueltos anualmente se redujo desde el año 2000.

Respecto al número de expedientes ingresados y resueltos, podemos afirmar que, en términos generales, se absorbe anualmente -aproximadamente y teniendo en cuenta la media del quinquenio- un volumen de trabajo cercano a la cantidad de expedientes que ingresan al año.

Lo anterior indica que la tasa de resolución (resueltos anuales/ingresados anuales) oscila alrededor del $100 \%$. Esto se traduce en que el volumen de recursos que se resuelven al año en el conjunto de los TEARs y TEALs es insuficiente para acabar con el ingente número de recursos pendientes de resolver que se arrastran de ejercicios anteriores. Como es lógico, si ingresan y se resuelven al año cerca de 150.000 expedientes y existen pendientes de resolver cerca de 230.000 acumulados, a dicha tasa de resolución no se logrará eliminar el arrastre. 
B. Segundo intervalo de referencia: 2001 a 2012-2013 ${ }^{[4]}$

TEARs y los TEALs España

\begin{tabular}{ccccccccc}
\hline Años & $\begin{array}{c}\text { Ptes. } \\
\text { inicio }\end{array}$ & Ingresados & Totales & Resueltos & $\begin{array}{c}\text { Ptes. } \\
\text { fin año }\end{array}$ & $\begin{array}{c}\text { Velocidad } \\
\text { resolución }\end{array}$ & $\begin{array}{c}\text { Tasa } \\
\text { eficacia }\end{array}$ & $\begin{array}{c}\text { Tasa de } \\
\text { resoluc. }\end{array}$ \\
\hline 2001 & 215.854 & 171.511 & 387.365 & 158.441 & 228.924 & 2,44 & 40,9 & 92,4 \\
2002 & 228.924 & 156.429 & 385.353 & 158.751 & 226.602 & 2,43 & 41,2 & 101,5 \\
2003 & 226.602 & 155.205 & 381.807 & 157.235 & 224.572 & 2,43 & 41,2 & 101,3 \\
2004 & 224.572 & 103.344 & 327.916 & 154.435 & 173.481 & 2,12 & 47,1 & 149,4 \\
2005 & 173.481 & 121.326 & 294.807 & 143.332 & 151.475 & 2,06 & 48,6 & 118,1 \\
2006 & 151.475 & 127.121 & 278.596 & 147.631 & 130.965 & 1,89 & 53 & 116,1 \\
2007 & 130.965 & 126.451 & 257.416 & 135.878 & 121.538 & 1,89 & 52,8 & 107,5 \\
2008 & 121.538 & 152.194 & 273.732 & 153.478 & 120.254 & 1,78 & 56,1 & 100,8 \\
2009 & 120.254 & 177.833 & 298.087 & 171.323 & 134.261 & 1,78 & 40,8 & 96,3 \\
2010 & 134.261 & 198.523 & 332.793 & 164.000 & 168.793 & 2,03 & 49,3 & 82,6 \\
2011 & 168.793 & 216.747 & 385.540 & 184.670 & 200.870 & 2,09 & 47,9 & 85,2 \\
2012 & 200.870 & 223.417 & 424.287 & 190.374 & 233.913 & 2,23 & 44,9 & 85,2 \\
\hline
\end{tabular}

Año 2013, expedientes pendientes al inicio: 233.913.

Al inicio del año 2001 ya existía un volumen de expedientes pendientes de resolver en el conjunto de tribunales regionales y locales de 215.854, cuantía que afortunadamente se redujo a partir del año 2005, pero que a partir del año 2010 ha experimentado un importante repunte, quedando a comienzos del año 2013 un volumen de expedientes pendientes de resolver de 233.913. Es decir que al inicio del año 2013 existían 18.059 expedientes más que a principios de 2001 (con un incremento cercano al 7.7\%).

La tasa de resolución (resueltos anuales/ingresados anuales) oscila alrededor del 100\%. En los años de bonanza se supera dicha tasa, alcanzándose el pico en 2004, con una tasa de resolución del $149 \%$; tasa que es algo superior al $100 \%$ en los años siguientes, y desde 2010 se vuelve a tasas de resolución del $80 \%$, es decir, sólo se logra resolver un $80 \%$ de los expedientes en relación a los expedientes anuales, sin tener en cuenta el acumulado.

4 Tabla aportada por Óscar Villar, profesor de Econometría de la Universidad de Barcelona y miembro del Proyecto FBg: 307839, "Alternative Dispute Resolution en Derecho Tributario comparado y su aplicación a la Administración tributaria de Catalunya". Investigadora principal: Eva Andres Aucejo. 
Todo ello tiene su traducción directa en la velocidad de resolución o tiempos de espera, que mide cuánto tiempo pasa como media desde que un recurso ingresa en el tribunal hasta que es resuelto ${ }^{5}$. Dicha tasa oscila alrededor de los dos años. Hasta 2005 se superan los dos años, durante 2006 a 2009 en términos generales se supera el año y medio, y a partir del año 2010 de nuevo se experimenta una tasa superior a los dos años, con tendencia creciente en los tiempos de espera.

Tal y como tuve ocasión de exponer ${ }^{6}$, hay que reparar en que las tasas de litigiosidad en el orden tributario se perpetúan en el tiempo, sin que se logre acabar con el acumulado, pues luego de una época de relativa mejoría (2005-2008) se regresa de nuevo a años de elevada litigiosidad, repitiéndose frecuentemente un acumulado de expedientes pendientes de resolver a principios de año en los tribunales económico administrativos. Así, en 1998 había pendientes al inicio del año 253.310 expedientes en los tribunales económico administrativos regionales y locales, y en el año 2013 continuaba habiendo pendientes 233.913 expedientes.

Cierto es que la tasa de resolución, en términos generales, es del orden del 80\% "anual", y a veces próxima o mayor a 1 (es decir, en el mejor de los casos se resuelve un volumen de expedientes equivalentes al número de cuestiones que se platean al año, o algo más. No sabemos si por LIFO o FIFO, eso no lo dicen las Memorias de la AEAT). Sin embargo, el número total de expedientes es dos y tres veces superior porque arrastramos un acumulado histórico. Es decir, al número de causas que entran al año en los tribunales económicos hay que sumarles los que existen acumulados sin resolver a principios de año. Ello se traduce en que las tasas de eficacia disten mucho de ser del $100 \%$, observando una velocidad de resolución con tasas que muchas veces superan los dos años.

De ahí la importancia de los sistemas de ADR, que en definitiva afectan a la variable "expedientes ingresados". Como es evidente, si se reducen los casos que entran, inmediatamente, con el mismo volumen de recursos y de trabajo, la productividad crece. Amén del ahorro consiguiente de todo tipo de costes. Por ello, es ahí precisamente donde se debería ahondar, como de hecho ya lo están haciendo las instituciones comunitarias en favor de los medios de resolución alternativa en general, y la mediación en particular.

A lo anterior se suman otros importantísimos problemas que necesitaríamos a toda consta conocer para poder hablar de un sistema eficaz. Por ejemplo, la Agencia Española de la Administración tributaria no hace públicos los datos sobre la litigiosidad que genera cada instancia (a saber, gestión, inspección, recaudación), ni tampoco hace público el importe de las cuantías de las

5 Velocidad de resolución $=$ pendientes al inicio +entradas en el año/resueltos totales al año.

6 ANDRÉs AuCEJo. Reclamo e mediazione tributaria, cit. 
liquidaciones dictadas por cada una de estas instancias. Si no conocemos quién genera la litigiosidad, ni el importe de las liquidaciones derivadas de las distintas actuaciones de la Administración tributaria, difícilmente se podrá solventar el problema.

En Italia, por ejemplo, como el 85\% de las liquidaciones recurridas en primera instancia de la jurisdicción tributaria es inferior a 20.000 euros (según datos oficiales de la Agenzia delle Entrate), se decidió legislar un mecanismo de reclamo y mediación obligatoria para aquellos expedientes que no superen dicha cuantía.

C. Sobre el "Tax gap"

La administración financiera se rehúsa constantemente a hacer público el Tax $g_{a p} p^{7}$, esto es, la diferencia entre lo que se espera recaudar y lo que se recauda efectivamente por declaración voluntaria. E igualmente se niega sistemáticamente a hacer públicos los costes de la Justicia. Y es un secreto a voces que los costes acarreados por los procedimientos administrativos que se inician contra los contribuyentes, con los consiguientes recursos que se arrastran en la fases administrativas y jurisdiccionales, a menudo superan con creces el beneficio obtenido.

Es mucho lo que que se podría aprender al respecto. Por ejemplo, en Italia, la Administración financiera no entabla un contencioso sin un estudio previo de probabilidades de éxito basado en experiencias previas de litigación. Y, siempre en Italia, la Administración revoca actos tributarios contrarios al contribuyente no sólo por razones de legalidad, sino también de oportunidad. Además, desde hace muchos años, altos cargos del Ministero dell'Economia y de la Agenzia delle Entrate instruyen circulares internas exigiendo a los órganos de la Administración conocer la líneas de la jurisprudencia nacional y comunitaria antes de incoar o seguir cualquier tipo de contencioso tributario con el contribuyente.

7 'Il 'tax gap' o perdita di gettito, indice dell'adesione spontanea ('compliance') al pagamento dei tributi, è la differenza tra l'ammontare delle imposte che l'amministrazione fiscale dovrebbe raccogliere e quello che effettivamente raccoglie. Il 'gap', o scarto, è suddiviso in tre tipologie: quando i contribuenti non presentano una dichiarazione dovuta o non lo fanno in tempo; quando i contribuenti sottostimano il loro reddito o sovrastimano esenzioni, deduzioni e crediti nelle dichiarazioni presentate in tempo; quando i contribuenti compilano la dichiarazione ma non pagano tutta la somma dovuta entro il termine (aggiornato il 6 giugno 2011)". 
3. REGULACIÓN VIGENTE EN DERECHO TRIBUTARIO ESPAÑOL.

LA ORFANDAD DE SISTEMAS DE ADR ${ }^{8}$

En términos generales podemos afirmar que, a lo largo de la historia del derecho tributario, el legislador español ha declinado la opción de incluir -ni en vía administrativa tributaria ni en vía económico administrativa- sistemas ad hoc de ADR tributarios como la mediación, el arbitraje y la conciliación.

Sí es cierto que en los distintos procedimientos tributarios, y fases del mismo, se han introducido ciertos conatos de sistemas de resolución convencional de litigios y algunas soluciones de carácter paccionado entre la Administración y los contribuyentes, aunque no han gozado de una gran efectividad a la hora de combatir el mal endémico de la litgiosidad tributaria.

Situación que a todas luces contrasta con la legislación tributaria de derecho comparado, donde los mecanismos extrajudiciales de resolución de conflictos (tanto en lo que concierne a los de carácter paccionado como a otras fórmulas transaccionales alternativas a la vía administrativa e incluso contenciosa) han gozado de gran predicamento y raigambre en las democracias occidentales de países con ordenamientos de corte continental (Alemania, Francia, Italia), como así también en países con ordenamientos de corte anglosajón (Estados Unidos, Reino Unido o Australia).

Situación que, lamentablemente, mal se comparece con lo acontecido en el ordenamiento "administrativo" español, donde - de lege data- se cuenta, desde 1992, con una auténtica regulación marco envolvente de las distintas fórmulas alternativas a la lite.

Así, mediante la Ley 30/1992 de Régimen Jurídico y Procedimiento Administrativo Común se tipifican distintas fórmulas alternativas que observan como denominador común la huida del litigio entre Administración y administrados, distinguiendo dos categorías bien diferenciadas, a saber: a) los acuerdos celebrados entre la Administración y el administrado (art. 88 Ley 30/92), acuerdos que suscitarían gran expectación por su carácter novedoso; b) los mecanismos de resolución de conflictos alternativos al tradicional recurso administrativo, como la mediación, la conciliación o el arbitraje, entre otros (art. 107 Ley 30/92).

En la vía jurisdiccional la Ley de la Jurisdicción Contencioso Administrativa sí prevé el mecanismo de la conciliación, aunque los tribunales no hacen uso del mismo.

8 Cfr. en AndrÉs AucEJo, E. Mecanismos convencionales y transaccionales de resolución de conflictos en Derecho Tributario Nacional y Comparado. La mediación en Derecho Tributario: una propuesta de lege ferenda. En Quincena Fiscal, n. ${ }^{\circ} 21,2010,13$ ss. 
Tipos de institutos alternativos convencionales de naturaleza tributaria y su naturaleza jurídica ${ }^{9}$

El estudio de los mecanismos alternativos de prevención y/o resolución de litigios de naturaleza tributaria en España puede sistematizarse del siguiente modo.

A. Técnicas paccionadas: "acuerdos" -cuyo máximo exponente lo constituyen las actas con acuerdo (figura tipificada en la LGT 58/2003)-, así como otras actuaciones tributarias entre Administración y contribuyente donde se hace patente una colaboración de este último en el procedimiento tributario (a título de ejemplo, los acuerdos previos de valoración).

\begin{tabular}{|c|c|c|}
\hline $\begin{array}{l}\text { Técnicas de prevención del litigio } \\
\text { en sede de gestión tributaria }\end{array}$ & $\begin{array}{l}\text { Técnicas de terminación } \\
\text { convencional del } \\
\text { procedimiento tributario }\end{array}$ & $\begin{array}{c}\text { Técnicas de terminación } \\
\text { convencional del } \\
\text { procedimiento tributario }\end{array}$ \\
\hline $\begin{array}{l}\text { Fase inicial del procedimiento de } \\
\text { gestión: autoliquidación: } \\
\text { Alternativas de filosofía } \\
\text { convencional }\end{array}$ & $\begin{array}{l}\text { Fase de comprobación e } \\
\text { Investigación del procedi- } \\
\text { miento inspector: } \\
\text { Alternativas cuasi-con- } \\
\text { vencionales y convencio- } \\
\text { nales }\end{array}$ & $\begin{array}{l}\text { Procedimiento de recau- } \\
\text { dación: } \\
\text { Alternativas convencio- } \\
\text { nales en fase de recau- } \\
\text { dación }\end{array}$ \\
\hline
\end{tabular}

Actos administrativos unilaterales participados:

- Actas de conformidad

- Acuerdos previos de valoración

- Propuestas en sede de impuesto de sociedades: planes de operaciones, gastos $\mathrm{i}+\mathrm{d}$, coeficiente de subcapitalización de amortización - planes de reparaciones extraordinarias, - propuestas de valoración de gastos de investigación científica - propuestas de imputación temporal de ingresos y gastos propuestas de planes especiales de reinversión.

- Operaciones vinculadas: propuestas de valoración sobre operaciones entre partes vinculadas, propuestas para deducción de gastos de $\mathrm{i}+\mathrm{d}$, coeficiente de subcapitalización... (acto administrativo unilateral con adhesión del contribuyente)

- Actas con acuerdo del contribuyente (acto administrativo acordado)
Acuerdos concursales en los procedimientos de quita y espera (acto administrativo Acordado) 
B. Otras técnicas transaccionales como la mediación, el arbitraje o la conciliación. A lo largo de la historia del derecho tributario, nuestro legislador ha declinado la opción de incluir técnicas propiamente transaccionales como la mediación, la conciliación o el arbitraje en tanto que mecanismos sustitutivos a la vía de revisión administrativa. Y ello a pesar de los intentos manifestados en esta línea -sobre todo en décadas más recientes- por parte de una significada doctrina, e incluso a pesar de los conatos que a favor de alguno de ellos (el arbitraje, sobre todo) se introdujeron en los textos previos que marcaron el proceso de gestación de la nueva LGT (L. 58/2003).

\subsection{Técnicas de prevención del litigio en materia tributaria en la fase de iniciación del procedimiento de gestión (autoliquidación del tributo) ${ }^{10}$}

Es bien sabido el proceso de generalización de las autoliquidaciones que tuvo lugar en el Estado español, con especial profusión, a partir de los años 1977-1978. La autoliquidación pasa así a erigirse en el sistema habitual de inicio del procedimiento tributario, en línea con lo acontecido en los países de paradigma anglosajón (que utilizan como moneda de curso la autoliquidación), e igualmente en línea con el paradigma continental que cada vez más ha ido haciendo uso de la técnica de la autoliquidación (Italia es el mayor exponente en dicho sentido).

El contribuyente se ve así compelido a realizar en unidad de acto la declaración, la calificación y la liquidación del tributo, a cuyo respecto a menudo le asaltan dudas sobre cómo interpretar, valorar y calificar el fenómeno tributario. Máxime teniendo en cuenta -como ha denunciado la doctrina- la gran cantidad de conceptos jurídicos indeterminados, presunciones, ficciones, normas defectuosas en su elaboración, excesivos reenvíos normativos o a veces casuística prolija e innecesaria en la formulación legal, además de lagunas, una espiral inflacionista de todo tipo de normativa infralegal, y un lamentable etcétera. Todo ello, qué duda cabe, aconseja la existencia de mecanismos convencionales no sólo de terminación del procedimiento tributario -que también-, sino tendente a evitarlo, dotando de mayor seguridad jurídica y certidumbre a la actuación del contribuyente. Son destacables los siguientes institutos jurídicos a los fines citados.

\section{A. Acuerdos sobre precios de valoración}

La vigente LGT tipifica los acuerdos previos de valoración en el artículo 91. Consisten en propuestas que realizan los obligados tributarios a la Adminis- 
tración sobre la valoración que se debe otorgar a rentas, productos, bienes, gastos y demás elementos determinantes de la deuda tributaria.

Régimen jurídico. Momento: se solicita con carácter previo a la realización de la autoliquidación (antes de realizar el hecho imponible o en los plazos reglamentarios). Forma: la solicitud se presenta por escrito junto con una propuesta de valoración formulada por el obligado tributario (contestando igualmente la Administración por escrito). Resolución: si no existe respuesta administrativa se aceptan los valores del administrado. Efectos: a) es vinculante para la Administración y el contribuyente, b) tiene un plazo máximo de vigencia de tres años, excepto norma en contrario, c) podrá modificarse siempre que varíen las circunstancias económicas o legislativas que fundamentan la valoración, d) no se pueden interponer recursos contra dicho acuerdo, sino contra el acto o actos que se dicten en aplicación de las valoraciones. Fin: evita la incertidumbre, incrementa la seguridad jurídica y por tanto previene la aparición del litigio.

Naturaleza jurídica: nótese que la ley reiteradamente utiliza la palabra acuerdo (art. 91.4, 5 y 6), si bien, tal y como ha observado un sector importante de la doctrina al que nos sumamos, no se trataría tanto de un acuerdo propiamente dicho sino de un acto de adhesión -en su caso- a la propuesta del obligado tributario. En este sentido, el denominado acuerdo previo de valoración no participa de la naturaleza transaccional. Se trata de un acto administrativo con la colaboración del contribuyente en el proceso de autoliquidación con el fin de evitar que se suscite un litigio ${ }^{11}$, considerándose por tanto como un acto administrativo dictado con la participación del contribuyente o participado ${ }^{12}$. Probablemente, lo más relevante a efectos de determinar la naturaleza jurídica tanto de los acuerdos previos de valoración

11 En este sentido se manifiestan: García-Herrera, C. y Herrera, P. Técnicas convencionales e igualdad tributaria. En Quincena Fiscal, n. ${ }^{\circ}$ 14, 2002; Rosembuj, quien los considera como actos de consenso o acuerdos no contractuales: Rosembus, T. La transacción tributaria. Atelier, 2000, 29 ss.; FERREIRo LAPATZA, Solución convencional de conflictos en el ámbito tributario: una propuesta concreta. En Quincena Fiscal, n. ${ }^{\circ}$ 9, 2003, 15 ss.; CAYÓN GALIARDO, prólogo a la obra de SERRANO ANTÓN, F. La terminación convencional de procedimientos tributarios y otras técnicas transaccionales. AEDAF, monografías, n. 9 9, 1996; GARcía NovoA, C. Mecanismos alternativos para la resolución de controversias tributarias: su introducción en el derecho español. En Rivista di Diritto tributario internazionale, 2002/2, 164-166, entre otros autores. Sin embargo, también pueden verse otras tesis inclinadas hacia la naturaleza convencional de este tipo de figuras: SERRANo ANTÓN. La terminación convencional de procedimientos tributarios y otras técnicas transaccionales, cit., 94, o también GonZÁLEZ-CuÉLLAR, quien otorga naturaleza de acuerdo transaccional a este tipo de propuestas en el caso de que sea aprobada por la Administración: GONZÁlEz-CuÉlLAR, L. Los procedimientos tributarios: su terminación transaccional. Madrid: Colex, 1997, 292-293; estos y otros autores también en García-Herrera y Herrera. Técnicas convencionales, cit., nota 58.

12 Véase sobre estos particulares, De Palma del Teso, Á. Las técnicas convencionales en los procedimientos administrativos. En Alternativas convencionales en el Derecho tributario. Madrid: Marcial Pons, 2003, 15 ss. 
in genere como de las propuestas solicitadas en relación a operaciones entre partes vinculadas (que veremos seguidamente) es el hecho de que la Administración no acuerda conjuntamente con el sujeto pasivo la valoración de los elementos u operaciones, sino que se limita a aceptar o rechazar la propuesta del obligado tributario (sin perjuicio de que quepa la aprobación de un plan alternativo por la Administración) ${ }^{13}$.

\section{B. Propuestas de valoración en el impuesto sobre sociedades}

Dentro del articulado del impuesto de sociedades encontramos algunas fórmulas que participan del carácter convencional, no tanto por tratarse de transacciones entre la Administración y los contribuyentes, pues no se produce una concesión de prestaciones recíprocas, sino por tratarse de alternativas al acto administrativo dictado unilateralmente por la Administración sustituyéndolo por un acto administrativo dictado con la colaboración del obligado tributario o acto administrativo participado. Se desarrollan en el Reglamento del Impuesto de Sociedades aprobado por RD 634/2015, de 10 de julio. A saber: planes de amortización (art. 7), planes de gastos correspondientes a actuaciones medioambientales (art. 10), planes especiales de inversiones y gastos de las comunidades titulares de montes vecinales en mano común (art. 11), acuerdos previos de valoración de operaciones entre personas o entidades vinculadas (arts. $21 \mathrm{ss}$.) ${ }^{14}$, acuerdos previos de valoración de operaciones vinculadas con otras administraciones tributarias (arts. 31 ss.), valoración previa de gastos correspondientes a proyectos de investigación científica o de innovación tecnológica (art. 38), acuerdos previos de valoración o de calificación y valoración de rentas procedentes de determinados activos intangibles (arts. 39 ss.).

\subsection{Sistemas convencionales de terminación de litigios en el procedimiento de liquidación español}

El resultado de las actuaciones de comprobación e investigación inspectoras se documenta en las actas de inspección firmadas por el funcionario y el obligado tributario. A los efectos que nos ocupan, existen dos institutos jurídicos que son en menor o mayor grado de naturaleza convencional, cuales son las actas de conformidad y las actas con acuerdo del contribuyente. En relación a las primeras, "actas de conformidad"15, se trata de una figura

13 Por todos FerReiro. Solución convencional, cit., 13.

14 Igualmente en el ámbito del Impuesto sobre la Renta de las Personas Físicas (arts. 19.7 LIS y 41 RIRPF).

15 Sobre el tema véase NAVARRo Egea, M. Notas sobre la conformidad del interesado con las actas de la inspección. En Quincena Fiscal, n. ${ }^{\circ}$ 9, 2001, 9 ss. 
establecida de antaño en nuestra legislación tributaria, consistente en que el contribuyente inspeccionado al cual se le regulariza su situación tributaria presta su conformidad con dicha propuesta de regularización. La principal característica de este instituto es que el sujeto pasivo presta su adquiescencia a la propuesta que presenta la inspección de los tributos, llevando aparejada dicha conformidad una reducción de las sanciones que en su caso procedan.

Adviértase por tanto que las actuaciones de fijación de hechos y calificación jurídica se llevan a cabo durante el procedimiento de comprobación e investigación inspector, sin que exista una transacción ni un intercambio de concesiones recíprocas entre las partes, por lo que respecto a esta figura no deja de perder aquí su virtualidad la teoría del acto administrativo unilateralmente dictado por la Administración, sin perjuicio de que exista una intervención del contribuyente aceptando o allanándose a la propuesta de regularización de la inspección. Ello ha llevado a considerar a parte de la doctrina - posición que asumo- la ausencia del elemento transaccional en las actas de conformidad. En la conformidad -se esgrime- "no existe un acuerdo de voluntades, lo que determina que no sea un contrato" ${ }^{16}$. Respecto a la naturaleza jurídica de dichas actas con acuerdo se ha defendido su diverso contenido: "con respecto a los hechos, se trata de una confesión extrajudicial, con respecto a las calificaciones jurídicas, es un acto de adhesión, acto que sirve de vehículo transaccional sobre comportamientos" ${ }^{17}$.

\section{A. Actas con acuerdo}

El segundo de los institutos tributarios citados se refiere a las actas con acuerdo del contribuyente. Se tipifican por primera vez en la Ley 58/2003, General Tributaria, y su adopción se produjo no sin un gran recelo por parte de la Administración tributaria española, reticente y temerosa ante las consecuencias que una figura de este tipo pudiera acarrear. Posiblemente los principales factores que motivaron su acogida fueron:

16 GonZÁLEZ-CuÉlLAR, L. Las actas de conformidad y las actas con acuerdo en la nueva LGT, disponible en: http://e-archivo.uc3m.es/bitstream/handle/10016/12035/actas_gonzalezcuellar_2007.pdf?sequence=1; ARRIETA, J. Las actas de la inspección de los tributos. Civitas, 1994, 368, e Íd. Finalización convencional del procedimiento tributario. En Convención y arbitraje en derecho tributario. Madrid: IEF, Marcial Pons, 1996, 194 ss.; GarCÍA-Herrera y Herrera. Técnicas transaccionales, cit., 27; Cayón Galiardo, A. Prólogo a La terminación convencional, cit., 6; MARTíNEZ MuÑoz, Y. Las actas con acuerdo en la nueva LGT. Madrid: MP, 2004, 61; LondoÑo GutiéRrez, F. Procedimientos alternativos de prevención y resolución de conflictos tributarios. FdI, 2006. En contra de esta tesis, otros autores defienden la naturaleza transaccional del acta de conformidad: "El acuerdo tiene naturaleza transaccional; siendo el acta de conformidad un instrumento de recíprocas concesiones para concluir o evitar futuros litigios":

Rosembuj. La transacción, cit., 55, entre otros autores.

17 ArRIETA. Finalización convencional, cit., 195. 
i. Hacía once años, por Ley 30/1992, LRJ y PAC, se habían implantado los acuerdos administrativos en sede de procedimiento; ley que potenció extraordinariamente su acogida tanto en derecho administrativo como en derecho tributario, donde, sabido es, dicha ley rige con carácter supletorio.

ii. Del año 1998 data la Ley 1/1998, de Derechos y Garantías de los Contribuyentes, ley que, sin perjuicio de las críticas auspiciadas en relación con la técnica legislativa empleada, nace con vocación de equilibrar las situaciones jurídicas entre la Administración y los contribuyentes con la finalidad de favorecer un mejor cumplimiento voluntario de estas ${ }^{18}$.

iii. Cabría argüir, asimismo, la extensión y consolidación del principio constitucional sobre participación ciudadana en la Administración (art. 23 $\mathrm{CE})$. De manera análoga a lo acontecido en derecho administrativo, en derecho tributario el procedimiento tributario ha ido cobrando una nueva dimensión. "El procedimiento es la sede en que se hace efectiva la participación de los interesados en la actividad administrativa"19. También en gestión administrativa tributaria han ido obteniendo mayores cuotas de participación los contribuyentes, como han puesto de manifiesto diversos estudios doctrinales relativos a la terminación convencional de los procedimientos tributarios ${ }^{20}$.

iv. Sin duda, también pesaron en su adopción las altas tasas de litigiosidad ante los tribunales que conocen de materia tributaria. Con todo, hubo que combatir las fuertes reticencias gubernamentales y administrativas hacia dichas figuras convencionales, a cuyo fin se hizo uso de dos importantes instrumentos: la estadística y el derecho comparado. Diversos estudios sobre litigiosidad en materia tributaria evidenciaron que la litigiosidad en el

18 Véase Andrés Aucejo, E. Desarrollo de los derechos constitucionales del los contribuyentes en el ordenamiento tributario español. En Foros y Debates, XXV Jornadas Latinoamericanas y XXXIV Colombianas de Derecho Tributario, 2010, Cartagena de Indias, 557 ss., e Íd. y Raventós-Calvo. Taxpayer rights and guarantees in the Spanish legal system. En The Confédération Fiscale Européenne at 50 Years. Part Two: A special focus on taxpayers rights and taxpayers charters. Servaas van Thiel, coord. Bruxelas: Confédération Fiscale Europeénne/ Datev, 2009.

19 De Palma. Las técnicas convencionales, cit., 16. Ver Gayón Galiardo, A. La interdicción de la discrecionalidad en la gestión tributaria. En $R E D F$, n. $^{\circ} 36,1982$.

20 STIPo, M. L'accertamento con adesione del contribuente ex D. legs. 19 giugno 1997, n. 218 , nel quadro generale delle obbligazioni di diritto pubblico e il problema della natura giuridica. Rassegna tributaria, $n .^{\circ} 5 / 1998$, para quien corresponsabilizar a los ciudadanos en las relaciones administración pública-privados conduce a una más sólida implantación de la "democracia administrativa" y a la creación de un nuevos derechos fundamentales para el ciudadano en sus relaciones con la Administración pública (pp. 1233-1234); SERRANo AnTón. Terminación, cit., 20; ZoRnoza PÉrez, J. ¿Qué podemos aprender de las experiencias comparadas? Admisibilidad de los convenios, acuerdos y otras técnicas transaccionales en el Derecho tributario español. En Convención y arbitraje en derecho tributario. Madrid: Marcial Pons, 1996, 127; RosemBuj. La transacción, cit., 11 ss.; GonZÁlez-Cú́llar. Los procedimientos tributarios, cit., 50 ss.; BILBAO ESTRADA, I. Los acuerdos tendentes a la determinación de la obligación tributaria en la nueva LGT. Madrid: IEF, 2005, 165 ss.; entre otros autores. 
conjunto de órdenes tributarios (AEAT, tribunales económico administrativos y contencioso administrativos) no era solo un término manido, carente de cifras. Y las cifras alarmaban ${ }^{21}$. Por otro lado, estudios de la doctrina tributaria evidenciaban desde hacía años que nuestro entorno de derecho tributario comparado venía utilizando con éxito mecanismos alternativos de resolución de conflictos tributarios. De tales institutos dos sobresalían como posibles modelos para inspirar la figura del acuerdo tributario en el ordenamiento español: el accertamento con adesione del contribuente en Italia y los acuerdos sobre hechos en Alemania. Desde Italia, con base en los observatorios Commissioni Tributarie, Agenzia delle Entrate-Ministero delle Finanze (Ufficio di Statistica), Istituto Nazionale di Statistica, concluimos investigaciones cualitativas/cuantitativas sobre la disminución exponencial sufrida en el número de nuevos litigios tributarios a consecuencia de la aplicación de estas técnicas extrajudiciales de resolución de conflictos ${ }^{22}$. Puede leerse al respecto en el Informe de la Comisión para la Reforma de la Ley General Tributaria: "dentro del Derecho comparado, el ordenamiento italiano ha sido objeto de especial atención, dada la similitud de ambos sistemas -el italiano y el español-y los éxitos conseguidos en aquel país". En este sentido también, el anteproyecto de la vigente LGT proclama como objetivo "la disminución de los niveles actuales de litigiosidad en materia tributaria".

Régimen jurídico de las actas con acuerdo. Inicio: la tramitación de un acta con posibilidad de acuerdo se configura como una potestad discrecional de la Administración ("la Administración tributaria... podrá", art. 155), habiéndose omitido, infortunadamente, la posibilidad de la solicitud por

21 Andrés Aucejo, E. y Royuela Mora, V. Análisis estadístico de las actuaciones inspectoras (Agencia Estatal de la Administración tributaria. Periodo: 1995-2000). En Revista Técnica Tributaria, n. ${ }^{\circ}$ 63, 2003, 17 ss.; Íd. "Análisis estadístico de la litigiosidad en los Tribunales de Justicia. Jurisdicción Contencioso-Administrativa (período 1990-2000)". Instituto de Estudios Fiscales, doc. n. ${ }^{\circ}$ 16/2003; Íd. "Análisis estadístico de la litigiosidad experimentada en el Tribunal Económico Administrativo Regional de Cataluña (1990-2000)". Instituto de Estudios Fiscales, doc. n. ${ }^{\circ}$ 25/2004; Íd. "Análisis estadístico de la litigiosidad experimentada en los Tribunales Económico Administrativo Regionales, Locales y en el Tribunal Económico Administrativo Central de España (1998-2002)". Instituto de Estudios Fiscales, doc. n..$^{\circ}$ 25/2004 (también en $C T$, n. $\left.^{\circ} 115,2005\right)$. Nota: estudios elaborados en los años 1999 y siguientes en el marco del Proyecto de Investigación del MEC, Ref. SEC 1999-0469. Sobre el tema también PASTOR PRIETO, S. y Marín-Barnuevo FABo, D. La litigiosidad tributaria: un análisis jurídico y económico. Madrid: IEF, 2005.

22 ANDRÉs AuCEJo. Evaluación de la litigiosidad en el "Rapporto tributario" en Italia, cit., 244-278; Íd. L'evoluzione della litigiosità nelle "commissioni tributarie" italiane nel corso degli anni 1990-2000, cit.; Íd. La resolución alternativa de conflictos tributarios en Italia, cit. Por su parte, también en Alemania se evidencia una drástica reducción de la litigiosidad tributaria al ser absorbidos por la vía del acuerdo gran parte de las contiendas entre la Administración y los contribuyentes. Así Martín Lobenhofer y García Frías. Resolución alternativa de conflictos tributarios en Alemania. La aplicación práctica de los acuerdos sobre hechos. En Quincena Fiscal, n. ${ }^{\circ}$ 6, 2004. 
parte del contribuyente ${ }^{23}$, a diferencia de los acuerdos en derecho italiano o de las fórmulas transaccionales en los países anglosajones. Instrucción: el procedimiento para la suscripción de las actas con acuerdo tiene lugar en el seno del procedimiento inspector, no habiéndose previsto un procedimiento separado al inspector a tales efectos ${ }^{24}$. Respecto a los motivos, las actas con acuerdo se prevén para supuestos de especial dificultad en la aplicación de la norma concreta o para la estimación o valoración de elementos de la obligación tributaria de incierta cuantificación. En particular: la concreción de conceptos jurídicos indeterminados; la apreciación de hechos determinantes para la correcta aplicación de la normativa; y, también, la necesidad de realizar estimaciones, valoraciones o mediciones de datos, elementos o características relevantes para la cuantificación cierta de la obligación tributaria. El acuerdo se perfecciona con la suscripción del acta por el contribuyente y la Administración, a cuyo fin se establecen legalmente unas garantías previas y especialidades en el pago. Son efectos derivados del acuerdo, la reducción de sanciones impuestas, que alcanza al 50\%, así como la imposibilidad de impugnar la liquidación y la sanción derivadas del acuerdo, que sólo podrá ser revisada en vía administrativa por el procedimiento de nulidad de pleno derecho, sin perjuicio del recurso contencioso administrativo por la existencia de vicios en el consentimiento.

Finalmente y por lo que respecta al controvertido tema de la naturaleza jurídica de las actas con acuerdo, ha sido la doctrina italiana (habida cuenta del profundo arraigo de la figura tributaria del concordato) quien ha formulado las principales teorías a efectos de su catalogación, a saber ${ }^{25}$ : 1 . Acto unilateral de la Administración (Giannini, Ingrosso, Griziotti, etc.); 2. Acto

23 En este sentido también Ferreiro Lapatza. Solución convencional, cit., 17; GonzálezCú́llar. Las actas de conformidad, cit., p. 475, autora que además denuncia con buen criterio el hecho de que el artículo 155.7 LGT excluya como motivo de impugnación del acto de liquidación la decisión del inspector de no resolver la cuestión incierta mediante un acuerdo, "pues convierte una decisión discrecional en arbitraria".

24 Sobre las cuestiones que suscita el procedimiento de las actas con acuerdo puede verse: Bilbao Estrada, I. Cuestiones procedimentales en materia de actas con acuerdo a la luz del Proyecto de Reglamento general de las actuaciones y los procedimientos de gestión e inspección tributaria y otras normas tributarias. En $C T$, n. ${ }^{\circ} 122,2007$; GARCíA-HERRERA, C. y HERRERA Molina, P. Reflexiones sobre el procedimiento y régimen jurídico de las actas con acuerdo. En La aplicación de los tributos en la nueva LGT. XLIX Semana de Estudios de Derecho Financiero. Madrid: MeH, 2005, 519 ss.; García-OvíEs, I. Capítulo vi. Procedimiento de Inspección. En La nueva Ley General Tributaria. Madrid: Civitas, 2004, 478 ss.; GIL Cruz, E. Las actas con acuerdo en el Procedimiento inspector. Aranzadi, 2009, 235 ss.; GonZÁLEZ-CuÉlLAR. Las actas, cit.; entre otros.

25 Una exposición más completa puede verse en Andrés Aucejo, E. Los instrumentos deflactivos del contencioso tributario en Italia. En especial 'L'accertamento con adesione'. Análisis cualitativo y cuantitativo. Rivista di Diritto tributario internazionale (International Tax Law Review), n. ${ }^{\circ} 2$, 2002, pp. 200-243, e Íd. La resolución alternativa de conflictos tributarios en Italia, cit., 56 ss. 
bilateral: contrato transaccional (Carnelutti, Vanoni, Allorio, Russo, etc.); 3. Posición ecléctica: teoría del acuerdo administrativo (Stipo, Versiglioni). Entre la doctrina española, las tesis sobre la naturaleza jurídica de las actas con acuerdo oscilan desde su catalogación como "acuerdo procedimental" 26 -esto es, acuerdos entre la Administración y los sujetos en el curso de un procedimiento administrativo que desembocan en la emisión de un acto administrativo con acuerdo del contribuyente ${ }^{27}$ - hasta las posiciones de los autores más próximos a la teoría transaccional aplicada al derecho público ${ }^{28}$. Se defiende asimismo su clasificación como negocio jurídico de fijación ${ }^{29}$.

\subsection{Alternativas convencionales en fase de recaudación en España}

La materia específica de acuerdos concursales por parte de la Administración tributaria incursa, es una de las pioneras actividades convencionales tipificadas primero en nuestra legislación presupuestaria (art. 39.2 TRLGP anterior, introducido por Ley de Presupuestos de 1989) y posteriormente también en sede tributaria ex antiguo artículo 129.4 LGT (introducido por la Ley de modificación parcial 25/1995, de 20 de julio, de la LGT de 1963) ${ }^{30}$.

26 Siguiendo la teoría administrativa de los acuerdos procedimentales del derecho administrativo (De PaLma. Las técnicas convencionales, cit., 15 ss.

27 Tesis mantenida por FERreiro LAPATAZA. Resolución extrajudicial, cit., 15; seguida por las autoras: MARTíNEZ MuÑoz. Las actas con acuerdo, cit., 181-182 y GIL CRUz. Las actas con acuerdo, cit., 112 y 122 ss.

28 Rosembuj. La transacción tributaria, cit., 55 (para actas de conformidad); GonZÁLEZCuÉllAR. Las actas de conformidad, cit., 467: "La constatación de la naturaleza contractual de las actas con acuerdo [...] determina su régimen jurídico".

29 GonzÁlez-CuÉllar. Los procedimientos tributarios, cit., 77; Bilbao Estrada. Los acuerdos tendentes a la determinación de la obligación tributaria en la nueva LGT. Madrid: IEF, 337 ss.; Calvo Ortega, R. Los acuerdos fiscales. En Aa.vv. Estudios en Homenaje al Profesor Pérez de Ayala. Dykinson, 2007, 455. Sobre estos particulares ponemos de manifiesto la dicotomía existente entre la doctrina. FERREIRO afirma que "el negocio jurídico bilateral se caracteriza por una constituir, modificar o extinguir una obligación mientras que el acuerdo se refiere a una obligación ya nacida estableciendo únicamente los términos en que la ley ha de aplicarse a unos hechos concretos": Resolución, cit. GIL CRUZ, seguidora de este autor, afirma que lo que caracteriza a los negocios jurídicos, con independencia de la categoría a la que pertenezcan, es crear, modificar o extinguir una relación jurídica: Las actas con acuerdo, cit., 124. Sin embargo el sector doctrinal que defiende la teoría del negocio jurídico de fijación establece que las partes sólo buscan fijar los elementos inciertos de la obligación tributaria pero no crear ni modificar la obligación tributaria (ver nota 26). Finalmente autores de derecho administrativo distinguen entre "acuerdos de fijación" y "acuerdos de transacción": "Es importante subrayar la diferencia entre estas dos clases de acuerdo, pues en nuestro Derecho público, en ocasiones, se ha utilizado la expresión transacción como sinónimo de acuerdo [...]. La transacción es un negocio sinalagmático caracterizado por las recíprocas concesiones. El negocio de fijación tiene por objeto dar certeza a hechos o situaciones inciertas, eliminar una incertidumbre. En este caso no hay recíprocas concesiones": De PALMA. Las técnicas convencionales, cit., 29-30.

30 García-Herrera y Herrera Molina. Técnicas convencionales, cit., 15. 
Actualmente tanto el artículo artículo 164.4 LGT (58/2003) como el artículo 10.2 de la Ley General Presupuestaria (L. 47/2003, de 26 de noviembre) reconocen a la Hacienda Pública el derecho a suscribir auténticos acuerdos o convenios (previstos en la legislación concursal), así como a acordar de conformidad con el deudor y con las garantías que se estimen oportunas unas condiciones singulares de pago. A tal fin: se requiere autorización del órgano competente de la Administración tributaria (art. 164.4 LGT); dicho privilegio deberá establecerse en los términos previstos en la legislación concursal, y las condiciones singulares de pago no podrán ser más favorables para el deudor que las recogidas en el convenio o acuerdo que ponga fin al proceso judicial. La justificación de estos pactos estriba en el peligro que entraña el proceso concursal a efectos de la íntegra realización del crédito tributario, conllevando su implantación una excepción al principio de indisponibilidad del crédito tributario al tiempo que una facultad dispositiva sobre el mismo ${ }^{31}$.

Otras técnicas transaccionales en derecho tributario alternativas al procedimiento revisor

A lo largo de la historia del derecho tributario, nuestro legislador ha declinado la opción de incluir técnicas propiamente transaccionales como la mediación, la conciliación o el arbitraje en tanto que mecanismos sustitutivos a la vía de revisión administrativa. Y ello a pesar de los intentos manifestados en esta línea -sobre todo en las décadas más recientes- por parte de una significada doctrina, e incluso a pesar de los conatos que a favor de alguna de ellas (el arbitraje, sobre todo) se hicieron en los textos previos que marcaron el proceso de gestación de la nueva LGT (L. 58/2003) ${ }^{32}$, y que sin embargo la nueva LGT no tuvo a bien recoger, optando simplemente "por mantener el tradicional sistema de resolución de conflictos" (Soler Roch) ${ }^{33}$.

31 Véase, sobre estos particulares, VArona Alabern, J., El crédito tributario en la quiebra. Lex Nova, 2000, 278; Muñoz Merino, A., Privilegios del crédito tributario. Pamplona: Aranzadi, 1996, 201 ss.; González-CuÉllar, Los procedimientos tributarios, cit., 411 ss.; Mata Sierra, T. La condonación de la deuda tributaria en el marco de los procedimientos concursales. Madrid: Civitas, 1998, 57 ss.; entre otros.

32 En el Informe de la Comisión para la reforma de la LGT (2001) así como en el borrador del Anteproyecto de LGT de 2002, se incluía la figura del arbitraje en el derecho tributario como alternativa a la vía administrativa, opción que finalmente no se ha visto incluida en la LGT de 2003. "En el citado informe de 2001, la Comisión se pronunció, de forma casi unánime, a favor de la introducción de un arbitraje tributario, respecto del cual se formularon hasta tres propuestas diferentes, todas ellas instrumentadas como alternativa a los recursos administrativos". Soler Roch, M. Prólogo a Vicente-Arche Coloma, P. El arbitraje en el ordenamiento tributario español: una propuesta. Madrid: MP, 2005, 13.

33 Ibíd., 13. 


\begin{tabular}{|c|c|c|}
\hline Procedimiento de gestión & $\begin{array}{l}\text { Procedimiento } \\
\text { de recaudación }\end{array}$ & Procedimiento revisor \\
\hline $\begin{array}{l}\text { Tasación pericial } \\
\text { contradictoria (arts. } 57.2 \\
\text { LGT y } 161-162 \text { RGGI) }\end{array}$ & $\begin{array}{l}\text { Acciones extrajudiciales } \\
\text { de la Hacienda Pública } \\
\text { (art. } 7.3 \mathrm{LGP} \text { ) }\end{array}$ & $\begin{array}{l}\text { Técnicas transaccionales } \\
\text { alternativas al recurso } \\
\text { en vía de revisión }\end{array}$ \\
\hline $\begin{array}{l}\text { El laudo arbitral se incluye } \\
\text { en el acto administrativo } \\
\text { de liquidación, dictado } \\
\text { unilateralmente con } \\
\text { participación del arbitraje }\end{array}$ & $\begin{array}{l}\text { Cabe someter a arbitraje } \\
\text { los derechos de la } \\
\text { Hacienda Pública estatal } \\
\text { previo RD del Consejo de } \\
\text { Ministros }\end{array}$ & $\begin{array}{l}\text { El arbitraje tributario } \\
\text { sustitutivo del recurso } \\
\text { económico administrativo } \\
\text { no se ha legislado }\end{array}$ \\
\hline
\end{tabular}

a. El arbitraje en el ordenamiento tributario nacional

Como antecedente del arbitraje en derecho tributario se cita la figura de la tasación pericial contradictoria, actualmente regulada por los artículos 57.2 LGT y 161-162 del Reglamento de Gestión e Inspección, caracterizada por la intervención de un tercero independiente que actúa de árbitro para dirimir las discrepancias por diferencias de valoración (Administración-contribuyente). Nótese que este laudo "nunca puede tener carácter finalizador del procedimiento tributario", sino que se enmarca en el transcurso de las distintas fases del procedimiento de gestión o incluso antes, de forma que resuelve una cuestión del presupuesto de hecho que con posterioridad se recogerá en el acto de liquidación ${ }^{34}$. No se trata por tanto de una técnica creada $a h$ hoc como fórmula alternativa al recurso administrativo, amén de que en la práctica no ha servido para encauzar los numerosos conflictos, sobre todo en comprobaciones de valores por ITPAJD ${ }^{35}$.

i. El artículo 7.3 LGP (antiguo art. 39 LGP) prevé que la Hacienda Pública pueda someter a arbitraje los conflictos que se generen en relación a los derechos de la Hacienda Pública, si bien esta vía requiere en todo caso aprobación de un decreto acordado en Consejo de Ministros previa audiencia del Consejo de Estado en pleno.

ii. Respecto a la posibilidad de instaurar el arbitraje como fórmula alternativa al recurso económico administrativo existen interesantes propuestas que en todo caso pasan por su configuración legal ${ }^{36}$.

34 CRUZ PADIAL, I.El arbitraje tributario: una opción de futuro en la terminación convencional de procedimientos. En Carta Tributaria n. ${ }^{\circ} 310$, 1999, 9: "El laudo arbitral no sustituye al acto administrativo". GonZÁLEZ-Cú́LLAR, L. El arbitraje en derecho tributario. En RCEF, n. ㄱ, 1997, 42.

35 Delgado Pacheco, A. Las actas con acuerdo en la nueva Lgt. En Aa.vv. La aplicación de los tributos en la nueva LGT, Madrid: IEF, 2005, 420.

36 Véase el Informe de la Comisión para la Reforma de la LGT, 2001, cit.; VICENTE-ARCHE Coloma, El arbitraje en Derecho Tributario español: una propuesta, cit.; OlAÑETA, R. La creación de tribunales arbitrales en materia tributaria. En Tributos Locales, n. ${ }^{\circ}$ 32, 2003; GonZÁLEZCuÉllar. El arbitraje, cit.; Ferreiro Lapatza, Solución convencional, cit., p. 19; Calvo Ortega, 
El arbitraje en el marco legislativo de ciertas comunidades autónomas ${ }^{37}$.

i. Comisión arbitral del País Vasco para resolver los problemas entre las instituciones de las comunidades autónomas y las de los territorios históricos en relación a temas tributarios (art. 39 del Estatuto del País Vasco).

ii. Juntas arbitrales de la Comunidad Autónoma Foral de Navarra (creada por Ley 28/1990, de 26 de diciembre, art. 51) para resolver los conflictos que esta comunidad tenga con la Administración del Estado o con otra comunidad autónoma.

iii. Junta arbitral regulada en la LOFCA para la resolución de los puntos de conexión con los tributos dentro del ámbito de aplicación de la LOFCA (arts. 23 у 24).

El arbitraje en el marco de los entes locales

i. El Consell Tributari del Ayuntamiento de Barcelona incorpora entre sus funciones la proposición de resoluciones sobre los recursos planteados ante la corporación municipal de Barcelona, que en ningún caso tienen efectos vinculantes. "La intervención del Consell Tributari, por tanto, no sustituye al recurso administrativo [...] no determina una alternativa de procedimientos, ni es un mecanismo convencional. No es asimilable a la conciliación ni a la mediación porque no promueve pacto alguno entre la Administración y los contribuyentes. Y tampoco es propiamente un arbitraje, en primer lugar, porque la intervención del Consell es obligatoria y, en segundo lugar, porque sus propuestas no son vinculantes" (Agulló ${ }^{38}$ ). El artículo 2.1 a) del Reglamento del Consell Tributari (aprobado el 4/12/1987) atribuye al Consell el dictamen de todas las propuestas de resolución de recursos y reclamaciones que se presenten contra actos de aplicación de exacciones municipales y en general tributos locales ${ }^{39}$.

\subsection{Informes de los Comités de Expertos que elaboraron los trabajos preparatorios de la Ley General Tributaria (58/2003) en materia de mecanismos transaccionales de resolución de conflictos}

a. El Informe de la Comisión para el Estudio y propuesta de medidas para la reforma de la Ley General Tributaria: Informe para la reforma de la Ley

R. En defensa del arbitraje tributario. En $C T$, n. ${ }^{\circ} 100,2001$; FALCón y TelLA. El arbitraje tributario. Convención y arbitraje, cit., 257 ss.; García NovoA. Mecanismos alternativos, cit., 172 ss.; etc.

37 Véase Gil Cruz, Las actas con acuerdo, cit., 179 ss.; Merino JARA, I. Acerca de la “inexistente" Junta Arbitral del Concierto Económico. En Jurisprudencia Tributaria, n. ${ }^{\circ}$ 6, 2006 y recientemente: UTANDE SAN JuAN. Las Juntas Arbitrales del Concierto y el Convenio como vía para la resolución de conflictos forales. En Impuestos, vol. 26, n. ${ }^{\circ}$ 6, 2010, 11 ss.

38 La introducción en el derecho tributario español de las fórmulas convencionales previstas en la Ley 30/1992. Convención y arbitraje, cit., 188.

39 AA.vv., El Consell Tributari Municipal de Barcelona, Fundació Carles Pi i Sunyer, 1999. Sobre este órgano véase Tornos Más, J., El Consell Tributari del Ayuntament de Barcelona. En Documentación Administrativa , n. ${ }^{\circ} 220,1989$, y distintos estudios elaborados por A. Velasco, Garrido, T. Font I Llovet, I. De Lecea, etc., en Convención y arbitraje, cit. 
General Tributaria, Ministerio de Hacienda, Secretaría de Estado de Hacienda, 2001. En él se apuesta por la introducción de los siguientes institutos de resolución alternativa de conflictos tributarios:

i) Fase de aplicación de los tributos: medidas dirigidas a reducir la conflictividad en materia tributaria, donde destacan las fórmulas convencionales de terminación de los procedimientos tributarios. En particular, las actas con acuerdo y actas de conformidad con adhesión.

ii) Fase de revisión de los actos administrativos: el arbitraje tributario, constatándose tres posibles variantes ${ }^{40}$ :

- Arbitraje en derecho, encomendado a órganos administrativos especializados, funcionarios públicos que hayan superado las pruebas públicas establecidas al efecto. Dicho arbitraje se tendrá que llevar a cabo obligatoriamente en los supuestos que se tipifican (listado de posibles materias, algunas determinadas en función de su cuantía). El laudo puede ser recurrido en vía contencioso administrativa.

El arbitraje sería gratuito. Se señala que en el supuesto de contemplar costas al particular, habrá de preverse también la posibilidad de imponer costas a la Administración en términos equivalentes.

- Arbitraje en equidad, encomendado a órganos colegiados ajenos a la Administración, de carácter voluntario y limitado a asuntos de pequeña cuantía. Conocerían de estos caso el Consejo para la Defensa del Contribuyente.

- Arbitraje no limitado por razón de la cuantía, encomendado a árbitros independientes que consten, con requisitos de inscripción rigurosos, en los registros de Hacienda.

iii) Fase de revisión en vía administrativa o judicial. La conciliación ante los tribunales económico administrativos o la conciliación judicial.

b. El informe de la Comisión de expertos para el estudio del borrador del Anteproyecto de la nueva Ley General Tributaria: Informe sobre el borrador del Anteproyecto de la nueva Ley General Tributaria. Ministerio de Hacienda, Secretaría de Estado de Hacienda (23/01/2003).

En el preámbulo del Anteproyecto de la LGT se establece como uno de los objetivos básicos la diminución de los "niveles actuales de litigiosidad en materia tributaria", contemplándose entre otras figuras jurídicas "Las actas con acuerdo del contribuyente" (art. 155 Anteproyecto LGT) y "La revocación

40 "En el citado informe de 2001, la Comisión se pronunció, de forma casi unánime, a favor de la introducción de un arbitraje tributario, respecto del cual se formularon hasta tres propuestas diferentes, todas ellas instrumentadas como alternativa a los recursos administrativos": SOler Roch, M., prólogo El arbitraje en el ordenamiento tributario español: una propuesta, de Vicente-Arche Coloma, cit., p. 13. Véase también, sobre estos particulares, Ferreiro Lapatza, Solución convencional de conflictos en el ámbito tributario: una propuesta concreta. En Quincena Fiscal, n. ${ }^{\circ}$ 9, 2003. 
de los actos administrativos tributarios de gravamen o desfavorables para el contribuyente". El Anteproyecto de LGT no contempló el instituto del arbitraje en derecho tributario.

Es de constatar que en el informe elaborado por la Comisión de expertos sobre el borrador del Anteproyecto de LGT se aboga por la inclusión del instituto de la conciliación previa en vía económico administrativa, de manera que el recurrente pueda solicitar la celebración de un acto de conciliación como alternativa al procedimiento económico-administrativo. Supuesto un desacuerdo entre las partes, desembocaría en un arbitraje ante un órgano unipersonal del tribunal. En estos casos el arbitraje se sustanciaría ante los propios tribunales económicos administrativos (órgano unipersonal). Es decir, la propuesta no hace referencia a la intervención de órganos ajenos a la Administración sino que la competencia recairía sobre los propios tribunales económico administrativos.

\subsection{El anteproyecto de modificación parcial de la Ley 58/2003, de 17 de diciembre, General Tributaria ${ }^{41}$}

En el anteproyecto de Ley General Tributaria actual no se incorporan los Sistemas de ADR en materia tributaria. Una vez más, se desaprovecha la oportunidad de incluir en un texto legal las soluciones transaccionales como la mediación, la conciliación o el arbitraje en cuanto mecanismos de resolución de conflictos tributarios alternativos a la vía económico administrativa y/o judicial.

No es en absoluto un secreto y a las pruebas cabe remitir, la reticencia manifiesta y persistente por parte de la Administración tributaria a favor del instituto del arbitraje tributario. Trabajos a favor del arbitraje en el orden tributario no faltan, por lo que no insistiré más aquí al respecto, salvo dar noticia de ellos en ulteriores páginas de este escrito. Y si bien alguna explicación al respecto se ha ensayado, un motivo pudiera ser el privilegio de la autotutela de la Administración tributaria; ese poder histórico y omnímodo del que, como es bien sabido, goza también la Administración tributaria para hacer cumplir el derecho sin necesidad de acudir a los tribunales, "ni a los árbitros", máxime cuando el laudo del árbitro goza de inamovilidad (en puridad de concepto). Ese poder que en definitiva pudiera verse amenazado por un tercero independiente de la Administración capaz de dictar laudos arbitrales con la eficacia de cosa juzgada.

Sí es cierto que entre los objetivos de la nueva LGT está reducir significativamente la litigiosidad tributaria, y así por ejemplo se establece que

41 http://www.minhap.gob.es/Documentacion/Publico/NormativaDoctrina/Proyectos/ Tributarios/Anteproyecto\%20LGT.pdf 
uno de los objetivos perseguidos con la nueva regulación de los plazos del procedimiento inspector es precisamente ese.

Por lo que respecta al procedimiento económico administrativo, en el citado anteproyecto puede leerse:

El estudio de modificación del bloque normativo regulador de las reclamaciones económico-administrativas persigue dos objetivos básicos:

- La agilización de la actuación de los Tribunales y

- La reducción de la litigiosidad ${ }^{42}$.

\section{REFERENTES INTERNACIONALES. SISTEMAS DE ADR}

EN DERECHO TRIBUTARIO COMPARADO

En el presente epígrafe trataremos de resumir los principales mecanismos de resolución alternativa de conflictos tributarios y otros mecanismos que evitan el litigio, establecidos en derecho tributario comparado, siguiendo el siguiente esquema ${ }^{43}$ :

A.- Mecanismos que intentan evitar el litigio tributario para que este no surja

B.- Resolución alternativa de conflictos tributarios en vía administrativa

C.- Resolución alternativa de conflictos tributarios en vía jurisdiccional

42 "Para lograr tales objetivos, la reforma promueve una mayor y mejor utilización de medios electrónicos en todas las fases del procedimiento, agiliza los procedimientos y anticipa el sistema de establecimiento de la doctrina de los Tribunales y mejora técnicamente la normativa vigente, completando lagunas y clarificando algunos extremos que la práctica ha puesto de manifiesto como dudosos y, en cuanto tales, generadores de conflictos jurídicos.

Se suprime la regla especial de cómputo de plazo para recurrir en caso de silencio, de acuerdo con la reciente jurisprudencia del Tribunal Supremo y doctrina del Tribunal Económico Administrativo Central.

Se establece la posibilidad de suspensión de la resolución económico-administrativa en caso de presentación de recursos de alzada ordinarios por los Directores Generales si se dan determinadas circunstancias.

Se introducen mejoras en materia de recurso de anulación regulándose expresamente aquellos supuestos contra los que no procede dicho recurso.

Se crea un nuevo recurso, el de ejecución, llamado hasta ahora incidente de ejecución, contra actos dictados como consecuencia de una resolución estimatoria del Tribunal, clarificando el ámbito de aplicación objetivo, simplificando el procedimiento y estableciendo el carácter urgente en su tramitación.

Se reduce a seis meses el plazo de resolución del recurso extraordinario de revisión. Por último, se sustituye el procedimiento ante los órganos unipersonales por el procedimiento abreviado para las reclamaciones de menor cuantía en el que el tribunal podrá actuar de forma unipersonal".

43 Andrés Aucejo, E. y Alonso GonzÁlez, L. (dirs.), Alternative Dispute Resolution. En Derecho Tributario Comparado y su aplicación en la Administración tributaria de Cataluña, Generalitat de Catalunya, 2015, pp. 54 ss., disponible en: http://presidencia.gencat.cat/web/. content/ambits_actuacio/desenvolupament_autogovern/nou_model_adm_tributaria/06_sistemes_solucio_conflictes_tributaris.pdf 


\begin{tabular}{|c|c|c|c|}
\hline & \multirow[t]{2}{*}{ Estados Unidos } & \multicolumn{2}{|c|}{ Europa } \\
\hline & & Italia & Reino Unido \\
\hline \multirow[t]{6}{*}{$\begin{array}{l}\text { Sistemas } \\
\text { que evitan } \\
\text { el litigio }\end{array}$} & $\begin{array}{l}\text { a) Revenue Ruling/ } \\
\text { Procedure Ruling/ } \\
\text { Private Ruling }\end{array}$ & $\begin{array}{l}\text { a) "Interpello } \\
\text { tributario" }\end{array}$ & $\begin{array}{l}\text { a) Post-transaction } \\
\text { rulings. }\end{array}$ \\
\hline & $\begin{array}{l}\text { b) APAS (acuerdos } \\
\text { previos de }\end{array}$ & $\begin{array}{l}\text { b) APAS (acuerdos } \\
\text { previos de } \\
\text { valoración) }\end{array}$ & $\begin{array}{l}\text { b) APAS (advance } \\
\text { clearances) }\end{array}$ \\
\hline & valoración) & & c) Consultas \\
\hline & $\begin{array}{l}\text { c) Taxpayer's } \\
\text { Advocate }\end{array}$ & $\begin{array}{l}\text { c) "Garante del } \\
\text { contribuente" }\end{array}$ & $\begin{array}{l}\text { no vinculantes } \\
\text { (non statutory } \\
\text { clearances) }\end{array}$ \\
\hline & & $\begin{array}{l}\text { d) Revocación } \\
\text { tributaria }\end{array}$ & c) "Tax Assurance" \\
\hline & & e) Condono & $\begin{array}{l}\text { (similar al defensor } \\
\text { pero no recibe } \\
\text { quejas). }\end{array}$ \\
\hline \multirow{6}{*}{$\begin{array}{l}\text { ADR en vía } \\
\text { administra-tiva } \\
\text { tributaria }\end{array}$} & a) Mediation & $\begin{array}{l}\text { a) "Accertamento } \\
\text { con adesione del }\end{array}$ & a) "Agreements" \\
\hline & $\begin{array}{l}\text { b) Fast Track } \\
\text { Mediation }\end{array}$ & contribuente" & b) "Mediation" \\
\hline & c) Arbitration & $\begin{array}{l}\text { b) Reclamo/ } \\
\text { mediazione } \\
\text { tributaria }\end{array}$ & c) "Arbitration" \\
\hline & $\begin{array}{l}\text { d) Apelaciones } \\
\text { rápidas }\end{array}$ & c) Acquiescenza & \\
\hline & e) Acuerdos & & \\
\hline & f) Appels Office & & \\
\hline \multirow[t]{3}{*}{$\begin{array}{l}\text { ADR en vía } \\
\text { jurisdiccio-nal } \\
\text { tributaria }\end{array}$} & $\begin{array}{l}\text { Existen } 3 \text { tribunales } \\
\text { en primera } \\
\text { instancia: }\end{array}$ & $\begin{array}{l}\text { Conciliazione } \\
\text { giudiziale }\end{array}$ & $\begin{array}{l}\text { Conciliación en vía } \\
\text { jurisidiccional }\end{array}$ \\
\hline & $\begin{array}{l}\text { - US Tax Court } \\
\text { - US District Court } \\
\text { - US Court of } \\
\text { Claims }\end{array}$ & $\begin{array}{l}\text { Soccombenze } \\
\text { (imputación } \\
\text { en costas a la } \\
\text { Administración) } \\
\text { (no es ADR pero }\end{array}$ & \\
\hline & $\begin{array}{l}\text { Dos tribunales en } \\
\text { alzada: } \\
\text { - US Circuit Court } \\
\text { of Appels } \\
\text { - US Supreme } \\
\text { Court } \\
\text { No ADR en ninguna } \\
\text { instancia }\end{array}$ & evita litigiosidad) & \\
\hline
\end{tabular}




\begin{tabular}{|c|c|c|c|}
\hline & \multicolumn{3}{|c|}{ EUROPA } \\
\hline & Alemania & Francia & Holanda \\
\hline \multirow{2}{*}{$\begin{array}{l}\text { Sistemas } \\
\text { que evitan } \\
\text { el litigio }\end{array}$} & $\begin{array}{l}\text { a) Consultas } \\
\text { tributarias }\end{array}$ & $\begin{array}{l}\text { a) "Rescrit Fiscal" } \\
\text { (consultas) }\end{array}$ & a) Consultas \\
\hline & $\begin{array}{l}\text { c) Revisión } \\
\text { administrativa } \\
\text { (Einspruch) }\end{array}$ & $\begin{array}{l}\text { d) Revocación } \\
\text { tributaria }\end{array}$ & $\begin{array}{l}\text { b) APAS (advance } \\
\text { tax ruling) }\end{array}$ \\
\hline \multirow{3}{*}{$\begin{array}{l}\text { ADR en vía } \\
\text { administrativa } \\
\text { tributaria }\end{array}$} & $\begin{array}{l}\text { Acuerdos sobre } \\
\text { hechos (entrevista }\end{array}$ & a) Transacción & $\begin{array}{l}\text { a) "Agreements" en } \\
\text { vía administrativa }\end{array}$ \\
\hline & $\begin{array}{l}\text { final con el } \\
\text { Inspector Jefe). }\end{array}$ & $\begin{array}{l}\text { b) Conciliación/ } \\
\text { arbitraje }\end{array}$ & b) "Mediation" \\
\hline & & $\begin{array}{l}\text { Mediante diversas } \\
\text { comisiones } \\
\text { departamentales }\end{array}$ & $\begin{array}{l}\text { c) Arbitraje } \\
\text { internacional }\end{array}$ \\
\hline $\begin{array}{l}\text { ADR en vía } \\
\text { jurisdiccional } \\
\text { tributaria }\end{array}$ & $\begin{array}{l}\text { Conciliación en vía } \\
\text { jurisidiccional }\end{array}$ & $\begin{array}{l}\text { "Jurisidiction } \\
\text { gracieuse" }\end{array}$ & $\begin{array}{l}\text { "Agreements" en } \\
\text { vía jurisdiccional }\end{array}$ \\
\hline
\end{tabular}

\subsection{Estados Unidos: modelo por excelencia en materia de $A D R^{44}$}

Estados Unidos es uno de los Estados que con mayor alcance y profusión han legislado y reglamentado los sistemas de ADR.

A. Mecanismos que intentan evitar el litigio tributario para que este no surja

a. Revenue ruling (resoluciones tributarias interpretativas del IRS)/ Private ruling

En Estados Unidos el Departamento del Tesoro faculta a la agencia tributaria norteamericana (Internal Revenue Service, IRS) para dictar resoluciones interpretativas de las normas tributarias. En esta categoría de resoluciones se incluyen las consultas a la Administración tributaria.

Una revenue ruling es una resolución emitida por la agencia tributaria norteamericana (Internal Revenue Service, en adelante IRS), en la cual se contiene una interpretación del IRS sobre cómo aplicar la ley a unos hechos concretos. Consiste así en un instrumento de interpretación usado por la agencia tributaria norteamericana que tiene valor de fuente de ley primaria, y cuya finalidad es interpretar normas tributarias sustantivas para que puedan ser aplicadas a situaciones específicas.

44 Extraído de Andrés AucEJo, E., Las consultas tributarias en Estados Unidos. En Andrés Aucejo y Alonso González, dirs. Alternative Dispute Resolution, cit., pp. 54 ss. 
De la definición anterior deben remarcarse las siguientes características: se trata de resoluciones del Irs que sirven para interpretar normas tributarias, ya sea leyes (statutes, acts) o reglamentos; - estas resoluciones interpretativas aclaran únicamente normas sustantivas cuya aplicación al caso concreto no está lo suficientemente clara. Nota: en el supuesto de tratarse de normas de interpretación en materia de procedimientos tributarios e interpretación de aspectos adjetivos, entonces hablamos de "revenue procedures".

Las revenue ruling están diseñadas para resolver situaciones que no han sido adecuadamente tratadas por el código (Internal Revenue Code) y ante las cuales el IRS considera necesario analizar el problema aplicando su interpretación del código y trazando una solución. Es así como el IRs realiza su interpretación para que las normas tributarias puedan ser aplicadas. De hecho, la función de interpretar las normas tributarias para poder ser aplicadas es una obligación que le impone el código tributario al IRs, como veremos.

En realidad las revenue ruling son consultas tributarias que tienen interés general y por eso pueden ser aplicadas por otros contribuyentes que se encuentren en situación idéntica. Es decir, se trata de respuestas oficiales dadas por el IRS sobre preguntas de los contribuyentes concernientes a las consecuencias de una transacción propuesta.

Si en opinión del IRs la respuesta es significante para ser de aplicación general, la esencia de esta puede ser publicada en la forma de revenue ruling, de manera que puede ser también de aplicación por un mayor número de contribuyentes que estén en el mismo caso. Se debe ser muy cuidadoso con el hecho de no revelar la identidad del contribuyente.

Nota terminológica: hay que distinguir tres tipos de consultas:

1. Revenue ruling: se tiene cuando la Administración tributaria emite una respuesta a partir de la consulta de un contribuyente pero el IRS considera que tiene interés general, por lo cual se publica de forma oficial.

2. Revenue procedure: es igualmente una respuesta de la Administración tributaria que se publica siguiendo las mismas formalidades que para las $r e$ venue ruling, pero en donde el contenido se refiere a temas procedimentales.

3. Letters ruling: son también contestaciones a consultas realizadas por el contribuyente, pero en este caso la consulta no se extiende sino que únicamente se aplica al contribuyente que la solicita.

\section{b. El Defensor del Contribuyente en Estados Unidos}

Se trata de un organismo independiente del IRs, dirigido por el Abogado del Contribuyente (National Taxpayer Advocate). En cada estado o circunscripción del IRs existe, al menos, un delegado del Abogado del Contribuyente (Local Advocate Taxpayer), que tiene su oficina propia o bien trabaja en las 
sedes del IRS a través de las oficinas de resolución de conflictos de la agencia tributaria (Problem Resolution Office).

El Defensor del Contribuyente realiza dos funciones muy destacadas ${ }^{45}$ :

a. Examinar las situaciones de agravio que ante el mismo hacen valer los contribuyentes es lógico que identifique todo tipo de incidencias en la aplicación de los tributos: incongruencias de fondo o de forma, trámites prescindibles, contradicciones o lagunas formativas, plazos improcedentes, etc. No tiene competencia, pues, para dictar actos administrativos de determinación, liquidación, comprobación o recaudación de los tributos, aunque sí tiene potestad, en algunos supuestos, para suspender la tramitación y efectos de un procedimiento de gestión tributaria.

b. Resulta importante destacar la segunda función relativa al estudio, análisis y presentación de propuestas de reformas normativas o de pautas de actuación en la aplicación del sistema tributario que contribuyan a mejorar su eficiencia reduciendo, al mismo tiempo, la presión fiscal indirecta del contribuyente.

Se trata de una función importantísima habida cuenta de que el Defensor del Contribuyente, a la vista de las principales quejas y reclamaciones, realiza propuestas de reformas normativas de aquellas normas que no están funcionando correctamente, lo que sin duda es una medida deflactiva del contencioso. Se trata, en definitiva, de un cauce de participación en la política tributaria, incardinado en el conjunto de procedimientos de carácter colectivo. Así, se incardina el procedimiento denominado de systemic advocacy. La oficina del abogado responsable de este programa no tramita casos concretos. Se dedica a estudiar procedimientos, normas, políticas administrativas, prácticas organizativas, etc., que afectan a un buen número de contribuyentes y que condicionan el normal ejercicio de sus derechos, desestabilizando la equidad y eficacia del sistema.

\section{B. Alternative Dispute Resolution in tax matters in United States en vía administrativa ${ }^{46}$}

Sabida es la gran tradición que poseen en Estados Unidos las técnicas ADR, cuya Administrative Dispute Resoluction Act inicial data de 1996 y en la cual se tipifican distintas alternativas de resolución extrajudicial de disputas

45 Cfr. en Andrés Aucejo, E. y Rozas Valdés J. A., El Defensor del Contribuyente. Un estudio de derecho comparado: EE.UU. e Italia. En Documentos del Instituto de Estudios Fiscales, doc. n. ${ }^{\circ} 5 / 2004$.

46 Tomado de Andrés Aucejo, E., Resolucion alternativa de conflictos tributarios en Estados Unidos. En Andrés Aucejo et al., Alternative Dispute Resolution en Derecho Tributario Comparado, cit., pp. 279 ss. 
como la mediación, el arbitraje, la conciliación, el fact finding, el pequeño juicio, etc. ${ }^{47}$.

El contribuyente, si no llega a un acuerdo con los órganos tributarios del IRS, podrá optar por de las siguientes alternativas:

i. Activar cualquiera de los sistemas de ADR en derecho tributario regulados por el IRs: mediación, mediación en vía rápida, arbitraje, acuerdos en fase de liquidación ${ }^{48}$.

ii. Ir directamente a la Oficina de Apelaciones. También se puede acudir a la Oficina de Apelaciones en el caso de que se haya optado por algún sistema de ADR y no se haya conseguido ningún acuerdo.

iii. No entablar ningún sistema de resolución alternativa y optar directamente por los tribunales de justicia que conocen de la materia tributaria (ver infra, cap. V). En estos casos, sin embargo, no se podrá pedir la imputación en costas a la Administración.

a. Mediación. En 2009 se aprobó el procedimiento administrativo tributario: Revenue Procedure 2009-44, texto donde se actualiza el procedimiento de mediación, ampliando los casos que pueden acceder a la misma.

Con carácter general la mediación está disponible tanto para cuestiones jurídicas como para cuestiones de hecho, así como para otro tipo de cuestiones que se prevén expresamente en dicho procedimiento. Se caracteriza por las notas de voluntariedad, confidencialidad, prohibición de contactos entre partes y mediador independiente, entre otras.

El contribuyente puede solicitar la mediación si está en el curso de un procedimiento administrativo en relación con cualquiera de los asuntos disponibles para la mediación y el caso no es considerado como registrado ("non-docketed") ante cualquier Corte Tributaria. Si el contribuyente decide seguir adelante con la mediación, el primer paso en el proceso es presentar una solicitud formal de mediación con el Gerente del Equipo de Apelaciones (Appeals Team Manager). Con base en la experiencia, el proceso de mediación por lo general tarda entre 60 y 90 días.

b. La mediación de vía rápida. El IRs ha puesto en marcha el programa de prueba de "mediación de vía rápida" (Fast Track Mediation). Para iniciar el proceso, tanto el contribuyente como el encargado deben firmar un simple formulario de acuerdo a los efectos, luego de lo cual se asigna un medidor. Generalmente en menos de una semana, el mediador se pone en contacto

47 Véase dicha ley en: http://www.justice.gov/adr/pdf/adra.pdf, donde se prevé que los procedimientos administrativos se han vuelto cada vez más costosos y prolongados, lo que se traduce en gastos innecesarios de tiempo y en una menor probabilidad de lograr una resolución consensuada de las controversias. Véase Rosembuj, La transacción, cit., 84 ss.; SERRANo, La terminación, cit., pp. 32 ss.

48 Publication 4167 (Rev. 7-2012). Department of the Treasury International Revenue Service, en: www.irs.gov 
con el contribuyente y con el supervisor del IRS para planificar la reunión. Tras una breve explicación del proceso, el mediador discutirá con el contribuyente cuándo y dónde mantener la sesión de mediación. En dicha/s sesión/ es el mediador deberá ayudar a las partes a alcanzar un acuerdo satisfactorio conforme a la ley aplicable. Se prevé que el plazo medio debe ser inferior a 20-30 días, sin perjuicio de que cualquier parte puede retirarse del proceso antes de alcanzar una solución, notificándolo por escrito al mediador y a la parte contraria (Publication 3605 SP IRS).

c. Procesos de apelación rápida. En mayo de 2014, el IRs estableció el procedimiento de Apelaciones Rápidas ("Rapid Appeals Proces" o RAP). El RAP es un método electivo de resolución alternativa de conflictos. Está disponible para los contribuyentes que apelan ciertos casos de empresas grandes e internacionales ("Large Business \& International" o LB\&I), los cuales son asignados a un líder de caso del Equipo de Apelaciones (ACTL).

d. Procesos de acuerdo. Con el fin de reducir los riesgos de litigación, las partes consideran seriamente las ofertas de liquidación y arreglo. Los contribuyentes por lo general están de acuerdo en todo, o en una gran parte del incumplimiento, a cambio de una concesión del IRS con respecto a las penalidades.

e. Arbitraje. Originariamente se tipifica en el Código Tributario (ref. 1988): IRC, Sección 7123 (b) (2), en el que se dispone que el IRS deberá establecer un programa piloto de arbitraje obligatorio. El programa piloto se desarrolló el 18/01/2002 para dos años de duración y el 1/07/2003 se completó una prueba con una duración de un año. El 18 de octubre de 2006 el IRS anunció que el proceso de arbitraje de apelaciones ya no era un programa piloto sino un método alternativo más, pasando a ser regulado por el procedimiento tributario (Revenue Procedure 2006-44), en virtud del cual el arbitraje sólo cabe para cuestiones de hecho y no para cuestiones jurídicas, ni tampoco para cuestiones protocolizadas ante cualquier tribunal. En el arbitraje, el IRS y el contribuyente están de acuerdo en que un tercero tome una decisión sobre una cuestión de hecho, decisión que será vinculante para ambos.

f. Oficina de Apelaciones (Appeals Office). Si el contribuyente tampoco está de acuerdo podrá pedir que su caso sea revisado por la Oficina de Apelaciones (Appeals Office), servicio del IRs separado e independiente de la oficina o delegación que conoció del caso que se recurre. A esta oficina se accede tanto si existe indeterminación en la determinación de los hechos como en la calificación jurídica, siempre que exista margen razonable para dudar sobre la liquidación. Los encuentros o conferencias que tienen lugar ante la Oficina de Apelaciones son reuniones informales. El encuentro podrá ser en persona, por vía telefónica o por correspondencia. El contribuyente puede actuar mediante representante o, si lo desea, puede ser representado por un abogado, un contador público certificado o un agente registrado para 
ejercer ante el IRS. Si no llega a un acuerdo con el oficial de apelación, o no desea apelar dentro del IRS, puede o bien optar por una fórmula transaccional (mediación, etc.) o bien presentar su apelación ante un tribunal.

\subsection{Europa}

\subsubsection{Italia $^{49}$}

A. Mecanismos que intentan evitar que surja el litigio tributario.

a. Garante del contribuente ${ }^{50}$.El "Garante" no pertenece a los poderes clásicos del Estado (legislativo, ejecutivo, judicial), de manera que no ejerce poderes administrativos ni judiciales. No tiene naturaleza jurisdiccional, habida cuenta de que el artículo 102 de la Constitución italiana prohíbe la institución de nuevas jurisdicciones especiales. En sentido positivo, encajaría en el género de categorías jurídicas que integran el grupo de "Autorità" caracterizadas por las notas de imparcialidad, independencia, autonomía, garantía (como, p. ej., la Banca de Italia, la Autoridad para la garantía de las comunicaciones, etc.). Características que confirman y aseguran su configuración como órgano que está por encima de las partes (Administración-contribuyentes), con capacidad para denunciar los abusos y disfunciones cometidos en los sectores de interés público y que no recibe directivas de ningún tipo por parte del gobierno. Esto es, opera "in piena autonomia" respecto de la Administración.

b) Interpello tributario ${ }^{51}$. Es el derecho del contribuyente a solicitar el parecer de la Administración tributaria sobre una problemática especifica en relación a una diposición tributaria o respecto de una operación prospettata, o bien respecto de la aplicación de una norma antielusiva. "Si tratta, in sostanza, del diritto del contribuente 'a conoscere le conseguenze fiscali delle proprie azioni' $e$ di 'valutarne l'impatto sulla propria vita privata o d'affari'”." [L] finalità dell'interpello, in linea di principio, è quella di consentire la partecipazione del contribuente all'azione dell'amministrazione finanziaria; coinvolgerlo nelle attività dell'amministrazione finanziaria funzionali all'attuazione del tributo, in chiave collaborativa, nell'individuazione del trattamento fiscale applicabile alla fattispecie concreta. Con l'interpello (rectius gli interpelli) il legislatore ha inteso favorire 'forme di contatto tra amministrazione fi-

49 Cfr. en ANDRÉs AuceJo, E. La resolución alternativa de conflictos tributarios en Italia, Ministerio de Economía, IEF, 2008; Andrés AuCeJo y Rozas ValdÉs, "El Defensor del Contribuyente. Un estudio de derecho comparado: EE.UU. $e$ Italia", cit.

50 Ibíd.

51 Carinci, A., Voce interpello tributario en Italia. En Andrés Aucejo et al., Alternative Dispute Resolution en Derecho Tributario Comparado, cit., pp. 279 ss. 
nanziaria e contribuente già in sede amministrativa, al fine di garantire una sollecita acquisizione del tributo e di ridurre i profili di litigiosità connessi all'attuazione del prelievo tributario"”.

c. Autotutela della Amministrazione finanziaria ${ }^{52}$, institución oriunda del derecho administrativo, que -en Italia- desde 1992 se legisla también en materia tributaria. Se trata del instituto de la revocación administrativa de los actos tributarios desfavorables para el contribuyente. Se puede hacer uso de este instituto tanto en el momento inicial de coloquio con la Administración, así como una vez incoado un procedimiento de liquidación e incluso en fase contenciosa. Así, su alcance se extiende más allá del procedimiento de gestión/liquidación tributaria, habida cuenta de que se puede hacer uso del mismo incluso cuando el acto administrativo de naturaleza tributaria haya ganado firmeza administrativa y en los casos en que se esté pendiente de sentencia judicial, pero siempre que no haya recaído sentencia judicial firme sobre el fondo del asunto. En España desde 2003 se ha introducido la figura de la revocación tributaria en la LGT, sin embargo los regímenes jurídicos de ambas instituciones son distintos, siendo de mayor alcance la normativa prevista en el ordenamiento tributario italiano.

B. Mecanismos de resolución alternativa de conflictos tributarios en vía administrativa

a. La aquiescencia. Consiste en la ausencia de impugnación por parte del contribuyente, de manera que este se aviene al acto de accertamento (liquidación) girado por la Administración, obteniendo así una reducción de las sanciones. Este mecanismo vendría a ser el equivalente a las actas de conformidad legisladas en el ordenamiento tributario español.

b. El concordato tributario o "accertamento con adesione del contribuente" 53 . El accertamento con adesione es una figura de naturaleza convencional ínsita en el procedimiento de gestión tributaria italiano, por el cual Administración

52 Véase AndRÉs AucEJo, E., La revocación de oficio de los actos administrativos: retos para su adopción en la legislación tributaria española y su regulación jurídica en Italia. En Revista de Derecho Financiero y de Hacienda Pública, n. ${ }^{\circ}$ 268, 2003, pp. 281-318; Íd., La resolución alternativa de conflictos tributarios en Italia, Ministerio de Economía, IEF, 2008.

53 Un estudio amplio sobre el particular puede verse en ANDRÉs AucEJo, E., La resolución alternativa de conflictos tributaries en Italia, Instituto de Estudios Fiscales, 2008. Ver también de la misma autora: "Los instrumentos deflactivos del contencioso tributario en Italia. En especial 'L'accertamento con adesione'. Análisis cualitativo y cuantitativo", cit., p. 200, y "Evaluación de la litigiosidad en el Rapporto tributario in Italia", cit., pp. 244 y ss.; Íd. y RoYUELA MoRA, V.: L'evoluzione della litigiosità nelle commissioni tributarie italiane nel corso degli anni 1990-2000. En Diritto e pratica tributaria, 4/2004. 
y contribuyente -ya sea a instancia de oficio, ya sea a instancia de parteprocuran llegar a un acuerdo ante incertidumbres de hecho o de derecho sobre la determinación del débito tributario. Tal acuerdo se formaliza por escrito en el denominado "atto di accertamento con adesione" firmado por la Administración y suscrito por el contribuyente. La adhesión del sujeto y la consiguiente suscripción del accertamento comporta, de un lado, la reducción hasta un cuarto del mínimo de la sanción que en su caso hubiere correspondido y, de otro, la imposibilidad de impugnación, de manera que si el contribuyente perfecciona el acto mediante el ingreso de la deuda convenida, el atto di accertamento con adesione deviene eficaz, poniendo fin al procedimiento, no cabiendo recurso ulterior sobre su contenido; contenido que deberá respetar también la Administración, quien no podrá modificar el atto di accertamento salvo casos excepcionales tasados en la norma. Se desarrolla igualmente en fase de gestión tributaria, pero a diferencia del instituto anterior, entre Administración y contribuyente existe un contradittorio para la determinación de la deuda tributaria.

c. El "reclamo" y la "mediazione tributaria" 54 . Figuras creadas recientemente en el ordenamiento tributario italiano. Su utilización es obligatoria para litigios tributarios de cuantía inferior a 20.000 euros. Debe interpornerse necesariamente antes de entablar un litigio ante las comisiones tributarias provinciales en los supuestos que prevé la ley. El reclamo consiste en una revisión de oficio por la Administración tributaria, mientras que la mediazione se prevé como una especie de conciliación, realizada por órganos adscritos a la Administración tributaria pero completamente diferentes de los inspectores actuarios o gestores actuarios que han conocido del caso. Sin duda son dos institutos que podrían trasladarse sin ningún problema a nuestro sistema tributario y evitarían una gran cantidad de recursos con un bajo coste.

C. Mecanismos de resolución alternativa de conflictos tributarios en vía contencioso administrativa ${ }^{55}$

a. La "conciliazione giudiziale" es una figura jurídica legislada en el ordenamiento tributario italiano, actualmente prevista en el artículo 48 del Decreto Legislativo 546 de 31 de diciembre de 1992, según redacción dada por Decreto Legislativo 218 de 19 de junio de 1997, artículo 14. Trae su causa del instituto típico de la "transacción" disciplinado en el proceso civil italiano. La conciliazione giudiziale consiste en un procedimiento de resolución de

54 Un estudio amplio sobre el particular puede verse en ANDRÉs AuCEJo, Reclamo e mediazione tributaria nel Diritto tributario italiano. ¿Para cuándo en España?, cit.

55 Andrés Aucejo, La resolución alternativa de conflictos tributarios en Italia, cit. 
controversias desarrollado ante las commissioni provinciali mediante un acuerdo entre las partes. La conciliazione se perfecciona con el pago de las sumas convenidas en tiempo y forma. El instituto de la conciliazione giudiziale, habida cuenta de que tiene lugar en el proceso contencioso, se desarrolla ante las commissioni tributarie provinciali.

b. Soccombenze. Apenas iniciada la década de 1990 en Italia, tuvo lugar -tras largos años de discusión- una importante reforma en el proceso contencioso tributario cuya finalidad fue lograr la homogeneización del mismo. Así, en virtud de la delegación legislativa contenida en el artículo 30 de la Ley $413 / 1991$ vieron la luz los decretos legislativos 545/92 y 546/92 por mor de los cuales se transformó completamente la disciplina del contencioso tributario. Entre las materias que fueron objeto de reforma se encuentran las costas procesales. Por lo que a nosotros respecta, su regulación se desarrolla en los artículos 15 y 46 del Decreto Legislativo 546/1992. El artículo 15 establece -con carácter general- el régimen jurídico de las costas en el proceso tributario, previendo que estas se imputarán a la parte que pierda el juicio (soccombente), sin perjuicio de que el juez pueda compensar en todo o en parte los gastos del proceso.

\subsubsection{Francia ${ }^{56}$}

En el ordenamiento jurídico público francés y en particular en derecho tributario las soluciones alternativas de controversias han visto limitada su introducción por contravención al principio del orden público así como por las dificultades que entraña trasladar categorías jurídico-privadas al ámbito del derecho fiscal como consecuencia de la indisponibilidad del patrimonio público. No obstante ello, sí se ha hecho uso de algunas soluciones extrajudiciales en distintos momentos del procedimiento tributario. A saber:

a. El artículo $247.1 .^{\circ}$ y $2 .^{\circ}$ del Livre des procédures fiscales -LPF- regula el instituto denominado Jurisdiction gracieuse a cuyo tenor el contribuyente, tras haber sido investigado y sancionado, puede solicitar la condonación total o parcial de algunos impuestos (directos) y la condonación total o par-

56 Son reseñables los siguientes trabajos: Rosembus, T., "La transacción tributaria en Francia, Bélgica e Italia", Quincena Fiscal, 4/2004, pp. 9 ss.; SAnz Díaz-Palacios, J., Medidas fiscales con efecto reductor de la conflictividad en Francia. La transacción. En Técnicas convencionales en el ámbito tributario, Atelier, 2007, pp. 49 ss.; Tovillas Morán, J., Soluciones altrnativas de conflictos tributarios en Francia. En Andrés Aucejo et al., Alternative Dispute Resolution en Derecho Tributario Comparado, cit., pp. 232 ss.; CRUZ PADIAL, Las actas con acuerdo, cit., pp. 83-86, 87, 88 . 
cial de sanciones e intereses de demora, como consecuencia de situaciones de insolvencia. También podrá solicitar la condonación o una moderación del gravamen principal del que es deudor invocando motivos de apuros o de indigencia que le hagan imposible liberarse frente al Tesoro (Précis de Fiscalité, $\left.\mathrm{PF} / \mathrm{LVII} / 3 .{ }^{\circ} \mathrm{P} / \mathrm{T} 5,7756\right)$.

B. La transacción se prevé en el artículo 247.3. ${ }^{\circ}$ LPF y consiste en que la Administración puede otorgar, "por medio de transacción, una atenuación de multas o de recargos impositivos, cuando estas sanciones y, en su caso, los gravámenes a los que se añaden no sean firmes", en cuyo supuesto el contribuyente no podrá impugnar dicho acuerdo y la Administración deberá proceder a la reducción de las sanciones.

C. Mecanismos alternativos de naturaleza transaccional consistentes en comisiones departamentales constituidas por representantes de la Administración y de los ciudadanos a través de las diversas instituciones corporativas, creadas para intervenir o arbitrar en conflictos que se planteen entre la Administración y los contribuyentes. En concreto existen: la Comisión departamental de impuestos directos y del impuesto sobre la cifra de negocios; la Comisión departamental de conciliación y el Comité consultivo para la represión del abuso del derecho. La primera, Comisión departamental de impuestos directos, se constituye por el presidente del Tribunal Administrativo o quien este delegue, dos representantes de la Dirección General de Impuestos (con grado de inspector jefe) y tres representantes de los contribuyentes. Esta Comisión interviene sobre todo para dirimir controversias sobre: cuestiones de hecho relativas al importe del resultado industrial o comercial (no agrícola); condiciones de aplicación de exenciones o minoraciones fiscales a favor de nuevas empresas, etc. ${ }^{57}$.

La Comisión de Conciliación conoce -sin carácter vinculante- de las controversias sobre valoración de bienes como consecuencia de transmisiones de bienes inmuebles y muebles, navíos, fondos de comercio, etc., que deben liquidar derechos de registro o el impuesto sobre el patrimonio. Se compone de un magistrado y cuatro representantes de la Administración, un notario y tres representantes de los contribuyentes, y decide por mayoría y con voto cualificado del Presidente ${ }^{58}$.

57 Sanz Díaz-Palacios, ob. cit., p. 79; Ferreiro, La justicia tributaria, cit., pp. 181 ss.

58 Sin embargo dicho procedimiento también ha sido objeto de críticas desde el punto de vista práctico y teórico. Así Rosembuj, T., La transacción tributaria en Francia..., cit., pp. 11 ss. 


\subsubsection{Alemania. Alternativas de resolución de conflictos tributarios} en la República Federal Alemana ${ }^{59}$

De manera análoga y previa a lo acontecido en el ordenamiento español, en el sistema jurídico alemán existe una legislación sobre convenios en derecho público como fórmula convencional de terminación del procedimiento administrativo (con origen en la Ley de Procedimiento Administrativo de 1976), a diferencia del ordenamiento tributario donde el reconocimiento de tales mecanismos convencionales ha conocido mayores complejidades y dificultades. En el ordenamiento tributario alemán tienen cabida algunos institutos jurídicos de resolución de controversias tributarias alternativos a la vía judicial, a saber:

1. Soluciones pactadas entre la Administración y los contribuyentes a través de los denominados "acuerdos sobre hechos", llevados a cabo en fase de gestión tributaria, extrapolados a otros procedimientos tributarios. Por lo que a las soluciones paccionadas se refiere, tal y como ha señalado la doctrina, en derecho tributario alemán, desde el punto de vista práctico era incesante la utilización de toda suerte de acuerdos en sede tributaria. En el plano jurisprudencial, el Tribunal Federal de Finanzas (Bundesfinzhof, BFH) sí había reconocido la figura del acuerdo sobre hechos (SEER), mientras que desde el punto de vista legislativo las principales objeciones planteadas conciernen a la imperatividad del núcleo esencial del derecho tributario y al principio de legalidad reconocido en el artículo 81 de la Ordenanza Tributaria Alemana (отA). Sin perjuicio de lo cual y a favor a su "aceptación tácita", ha jugado el hecho de que en la propia OTA existiesen tipificados una serie de preceptos que podrían apuntalar la juridicidad de los acuerdos sobre hechos, como por ejemplo el deber de colaboración entre la Administración ( $\$ 89$ OTA) y los contribuyentes, o la posibilidad de admitir el mecanismo de la estimación o también la propia "entrevista final” (\$ 201 OTA) entre el inspector jefe y el contribuyente: "En la entrevista final se discutirán especialmente los hechos controvertidos, así como la calificación jurídica de los datos comprobados en la inspección y sus consecuencias tributaria" (parr. 1).

59 Son reseñables al respecto los siguientes estudios: AndRÉs AucEJo, E., Los institutos jurídicos de simplificación impositiva en la República Federal Alemana. En La tributación de la renta empresarial, Marcial Pons, 2008; SEER, R., Contratos, transacciones y otros acuerdos en Derecho tributario alemán, en Convención y arbitraje, cit., pp. 133 ss.; MARTín LOBENHOFER y GARCÍA FRÍAs, Resolución alternativa de conflictos tributarios en Alemania. La aplicación práctica de los acuerdos sobre hechos. En Quincena Fiscal, 6/2004; EhMcke, T. y Marín-BarnueVo Fabo, D., La revisión e impugnación de los actos tributarios en derecho alemán. En CT, 108/2003; sin perjuicio de otros estudios no monográficos sobre este tema; SERRANo ANTón, La terminación convencional, cit., p. 35, con cita de PARADA, Régimen jurídico de las Administraciones Públicas procedimiento administrativo, y DELGADo PIQUERAS, Terminación convencional del procedimiento administrativo. 
2. Mecanismos alternativos en fase de revisión administrativa. En el plano revisor en vía administrativa destaca el Recurso extrajudicial en vía administrativa ante el mismo órgano que dictó el acto: Einspruch. En la práctica funciona como una auténtica revocación, de manera que si el contribuyente no está de acuerdo con la liquidación, inmediatamente acudirá a la Administración, y de forma gratuita y libre pedirá que se revise el acto. La Administración deberá revisar completamente el expediente y si ve que se ha equivocado, proceder directamente a su modificación sin que resulte necesaria una resolución formal del recurso presentado ${ }^{60}$. Mediante este procedimiento se persiguen los siguientes fines: - tutelar la posición jurídica del contribuyente, en primer lugar; - controlar la actuación de la propia Administración; - servir de filtro para impedir o evitar que un gran número de causas lleguen a los tribunales.

3. Finalmente, también en sede contenciosa se ha defendido la posibilidad de llegar a acuerdos con apoyo en el párrafo 79.1 de la Ordenanza de los Tribunales Financieros donde se dispone que el tribunal puede invitar a las partes a una discusión sobre el objeto de la polémica y que en la práctica "lleva a menudo a un acuerdo entre las partes que obtiene los rasgos de una transacción judicial" ${ }^{61}$.

\subsubsection{Reino Unido ${ }^{62}$}

A. Mecanismos que intentan evitar que surja el litigio tributario

En el Reino Unido la Administración tributaria provee servicios de información y asistencia al contribuyente sobre la interpretación de la normativa tributaria en muy variadas condiciones y efectos, en función del objeto de la consulta, la materia y el modo de plantearla, considerándose por la jurisprudencia que tales competencias constituyen un margen legítimo de discrecionalidad compatible con el principio de legalidad.

A este respecto se distinguen cinco modalidades de actuaciones encaminadas a ofrecer al contribuyente información y asistencia en el cumplimiento de sus obligaciones tributarias, en sentido parecido a lo que al respecto se prevé en nuestra normativa general tributaria:

60 Ver su desarrollo en EHMCKe y MARín-BARnuevo FABo, La revisión e impugnación, cit.

61 SEER, Contratos, cit., pp. 147-148. En contra cita este autor a quienes consideran la ilicitud de tales transacciones al no existir una regulación específica y concreta sobre transacciones en vía jurisdiccional tributaria. Véase también EsPEJo, I., La mediación en derecho tributario alemán, en Andrés Aucejo et. al. En Alternative Dispute Resolution en Derecho Tributario Comparado, cit., pp. 327 ss.

62 Se toma la información de Rozas VALDÉs, J., El régimen jurídico de las consultas en el Reino Unido. En Andrés Aucejo et al., Alternative Dispute Resolution en Derecho Tributario Comparado, cit., pp. 91 ss. 


\section{i. Servicios de información.}

ii. Publicaciones. Catálogo documentación con carácter informativo con el objetivo de orientar al contribuyente sobre el modo de cumplimentar sus obligaciones tributarias.

iii. Información previa (advance clearances). En algunas leyes tributarias se prevé el deber de información anticipada de la Administración sobre determinadas transacciones y actuaciones llevadas a cabo por el contribuyente, de modo semejante a lo previsto sobre informaciones previas y acuerdos previos de valoración en nuestra LGT (arts. 90 y 91). Por ejemplo, en precios de transferencia, pensiones, pólizas de seguros de vida. Son equivalentes a nuestas consultas escritas.

iv. Consultas no vinculantes (non-statutory clearances). "Estas llamadas non-statutory clearances, consultas no reguladas por disposiciones legales sino reglamentarias, administrativas, a diferencia de lo que ocurre con las advance clearances, serían equivalentes a lo que en nuestro ordenamiento tributario se conoce como consultas escritas, a veces denominadas formal rulings, aun cuando también presenta un cierto paralelismo con las mismas lo referido en el epígrafe siguiente sobre las decisiones a posteriori, también llamadas informal rulings; con la diferencia sustancial de que estas se pueden presentar una vez se ha ultimado el negocio sobre el que se pregunta, mientras que las consultas, non-statutory clearances, se han de presentar con anterioridad a su consecución".

v. Decisiones a posteriori (post-transaction rulings). Se trata de información por escrito sobre la interpretación de la normativa tributaria en determinadas materias.

B. Mecanismos de resolución alternativa de conflictos tributarios en vía administrativa

"En el Reino Unido tanto la Administración tributaria como en la literatura científica se presenta lo relativo a las técnicas de resolución alternativa de conflictos tributarios, mediante mediación, acuerdos o, eventualmente, el recurso al arbitraje como una alternativa a la resolución del litigio ante los tribunales conforme a Derecho. Y es así como el foco del problema se ubica en el control de la discrecionalidad administrativa al respecto en cuanto a su margen de decisión en la formulación de acuerdos con el contribuyente606. Así pues, la Administración tributaria británica tiene publicados varios documentos oficiales que fijan su política al respecto y encomienda a un Commissioner, el Tax Assurance, una específica labor de vigilancia para garantizar que el sistema funciona adecuadamente y con sujeción a Derecho". 
C. Mecanismos de resolución alternativa de conflictos tributarios

en vía contencioso administrativa

En particular, las fórmulas convencionales ínsitas en el marco de los procedimientos tributarios se tipifican en la Sección 54, Parte v, Capítulo 9 de la Taxes Management Act de 1970, a cuyo tenor cabe la posibilidad de llegar a un acuerdo entre contribuyente e inspector -que conoce de la gestión de los impuestos directos-, susceptible de producirse en cualquier momento previo a la resolución del recurso por los tribunales.

\subsubsection{Suecia ${ }^{63}$}

En Suecia la regulación de las consultas tributarias se introdujo en 1951. Ciertamente las administraciones tributarias suecas están obligadas a informar a los contribuyentes sobre cuestiones relativas a la aplicación de los tributos. Pero cuando la cuestión entraña una mayor dificultad, el contribuyente puede hacer uso de la institución de las consultas tributarias o resoluciones anticipadas, con la ventaja del carácter vinculante de la respuesta, carácter del que carece la información dada por otros cauces. Se ha de señalar, como nota peculiar del ordenamiento sueco, la cual no encuentra un equivalente en otros países, que actualmente dentro de esta institución quedan comprendidas tanto las respuestas a las denominadas consultas tributarias como la emisión de resoluciones tributarias concretas, sobre los casos específicos presentados, con carácter previo a la realización de los hechos. En ambos casos tienen efecto vinculante para la Administración.

Otra característica relevante del régimen de las consultas en Suecia es que pueden ser instadas tanto por el contribuyente como por laAadministración.

\subsubsection{Holanda}

A. Mecanismos que intentan evitar que surja el litigio tributario ${ }^{64}$

Destaca sin duda la amplitud de miras con que se contempla la regulación jurídica de las consultas tributarias en Holanda. Sistema tildado de "abierto, flexible y caracterizado por su poca formalidad", de manera que "no existen formalidades que limiten ni a los sujetos que pueden plantear las consultas, ni la materia, ni existe un procedimiento formal por seguir por parte de la Administración tributaria para emitir su respuesta a la consulta planteada"

63 Cañal García, F., Resoluciones anticipadas y consultas tributarias en Suecia. En Andrés Aucejo et al., Alternative Dispute Resolution en Derecho Tributario Comparado, cit., pp. 83 ss.

64 Ferreiro Serret, E., Las consultas tributarias en los Países Bajos: Holanda. En Andrés Aucejo et al., Alternative Dispute Resolution en Derecho Tributario Comparado, cit., pp. 69 ss. 
(Ferreiro Serret). No obstante -afirma la misma autora- y ante tanta flexibilidad, a partir de 2001 el secretario de Estado de Hacienda adoptó ocho decretos dando mayor transparencia sobre todo respecto de los estados que tenían algún tipo de relación con los Países Bajos. Entre ellos el Decreto Ifz2004/125m sobre el procedimiento para la adopción de advance tax ruling (que vienen a ser una especie de APAS o acuerdos de valoración previa). Al margen de los supuestos específicos, "no existe límite sobre la materia respecto de la cual pueda plantearse una consulta, siempre que se trate de transacciones que aún no hayan tenido lugar".

B. Mecanismos de ADR en materia tributaria en vía administrativa

Curiosamente -afirma el profesor Rozas-, el uso de la mediación en el ámbito tributario arranca en Holanda en el año 2001, fruto de la iniciativa de dos funcionarios de su Administración tributaria y como consecuencia de un proyecto piloto -en el marco de una iniciativa más amplia, Meiation naast Rechtspraak (La mediación en el ordenamiento jurídico), que ha tenido continuidad en el tiempo y que se ha estabilizado.

La mediación se puede incardinar en cualquier fase del procedimiento administrativo, o judicial, y se lleva a cabo por empleados de la propia Administración tributaria que reúnen dos características. Por una parte, están registrados en el Instituto Holandés de Mediation Istituut), una institución independiente creada en 1995 y que cuenta con una división específica relativa a cuestiones tributarias628; de modo que han recibido formación específica para el desarrollo de tareas de mediación en situaciones de conflicto y trabajan conforme a las reglas de dicho Instituto, Mediation Reglement 2008, que incluyen un código de conducta del mediador, Gedragsregels voor de NMI.

Por otra parte, en la selección del mediador se es especialmente cuidadoso en la preservación de su neutralidad. Siendo Holanda un país no muy extenso, el mediador siempre procederá de una localización geográfica diferente a la del lugar en la que se ubica el conflicto ${ }^{65}$.

\subsection{Australia ${ }^{66}$}

Desde los años 1990 se han ido promoviendo sistemáticamente los procedimientos alternativos de resolución de conflictos en derecho administrativo

65 Rozas Valdés, J., La mediación y/o conciliación y el arbitraje en Derecho tributario. Régimen comparado: Holanda. En Andrés Aucejo et al., Alternative Dispute Resolution en Derecho Tributario Comparado, cit., pp. 309 ss.

66 Véase Serrat, M., Sistemas de mediación y/o conciliación en derecho tributario comparado: Australia. En Andrés Aucejo et al., Alternative Dispute Resolution en Derecho Tributario Comparado, cit., pp. 309 ss. 
y tributario (Facilitative processes, Advisory processes, Determinative processes, Blended dispute resolution processes).

Los procedimientos alternativos están muy desarrollados en Australia y es posible reconocer una progresiva integración y cultura de las ADR.

La variedad y el número de alternativas a las que se tiene acceso tanto desde el ámbito tributario como desde cualquier otra rama del derecho facilitan la resolución del conflicto entre las partes -en este caso entre la Administración tributaria y el contribuyente- simplificando sustancialmente el proceso y acortando el tiempo de resolución. El sistema australiano posee mecanismos alternativos, tanto en la fase administrativa como en las más altas instancias de los tribunales, que despliegan un amplio elenco de figuras y procesos adaptados con gran precisión a las demandas de las partes para llegar a un acuerdo, por lo que se puede reducir significativamente la necesidad de sentencia de los tribunales de todas las ramas del derecho. Sin embargo, a pesar de las múltiples alternativas existentes, el Gobierno Australiano no ve plenamente satisfechas sus expectativas respecto a la generalización de estas prácticas. Y es que, dentro del ámbito estrictamente tributario, el principal fallo en la implementación de estos mecanismos alternativos al litigio, tal y como denuncian la NADRAC y el IGT, se produce desde dentro de la propia Administración tributaria, por tanto, al objeto de potenciar y normalizar más su uso, y por las ventajas administrativas y económicas que supone el uso de estas técnicas, el Gobierno Australiano destina una extensa partida de recursos públicos al estudio y fomento de estas vías alternativas (Serrat).

\subsection{Latinoamérica}

En Latinoamérica son muy pocas las experiencias en materia de ADR en materia tributaria, esto debido a que -de manera análoga a lo que sucede en España-existen fuertes discrepancias respecto de estos sistemas ${ }^{67}$.

\section{A. Chile ${ }^{68}$}

En las páginas que preceden hemos podido citar cómo en Chile se han legislado las consultas tributarias, siendo un instrumento muy importante (Montecinos). También existe legislado el instituto jurídico de la revocación, como hemos citado (Contipelli), y los acuerdos tributarios en vía administrativa tributaria,

67 Al respecto recomiendo la lectura de la Rivista di Diritto tributario internazionale, 2002/2, donde tuve ocasión de publicar estudios al respecto, y donde se recogen toda una serie de estudios de Latinoamérica sobre la materia, fruto de una convención internacional en la que intervine, organizada por la Cátedra Jean Monet en Caserta, Italia, en el año 2002.

68 Véase Andrés Aucejo et al., Alternative Dispute Resolution en Derecho Tributario Comparado, cit. 
pese a no estar legislados, tienen una gran incidencia en la gestión tributaria ordinaria de la Administración tributaria con los contribuyentes (Masbernat).

\section{B. Colombia}

En Colombia se creó en el año 1999 la figura del Defensor del Contribuyente y Usuario Aduanero (en adelante, el Defensor), “con el fin de garantizar el respeto a los derechos de los contribuyentes, responsables, agentes de retención, declarantes y usuarios aduaneros, en las actuaciones que se cumplan en ejercicio de las funciones asignadas por la Ley a la Dirección de Impuestos y Aduanas Nacionales". El Defensor tiene jurisdicción a nivel nacional y cuenta con delegados regionales.

La Defensoría del Contribuyente y Usuario Aduanero constituye uno de los medios a través de los cuales los contribuyentes o usuarios aduaneros, directamente o a través de apoderado, pueden contactar con la Defensoría del Contribuyente y Usuario Aduanero (en adelante, Defensoría) administración tributaria nacional para registrar solicitudes, quejas, reclamos y/o sugerencias sobre temas tributarios, aduaneros y cambiarios que son de competencia del órgano especial y de igual forma, para consultar información relativa a su gestión.

Para el mejor cumplimiento de las funciones de defensa y siguiendo los parámetros legales, se ha establecido al interior de la DIAN un procedimiento para atender los requerimientos efectuados por las defensorías y originados en las solicitudes que le son presentadas, aportando las evidencias o información pertinente que soporta su intervención y de acuerdo a las circunstancias previstas.

Ha de tenerse presente que los conceptos emitidos por la Defensoría no obligan y que no le corresponde emitir respuestas técnicas; las solicitudes presentadas y las actuaciones ante ella realizadas, no constituyen una instancia ni interrumpen términos legales; así que, ante la vulneración de derechos por la DiAn en las actuaciones administrativas, el producto final de su gestión será emitir recomendaciones y presentar propuestas para mejorar el servicio fiscal ${ }^{69}$.

Por otra parte, en Colombia destacan "dos figuras que han colaborado muchísimo en la solución de controversias entre particulares y el Estado en materia tributaria, que se dan en sede administrativa en la etapa de discusión de los actos liquidatorios y sancionatorios y del recurso extraordinario de revocatoria directa. Una de ellas es el silencio administrativo positivo y, la otra la

69 Posada, D., La defensoría del contribuyente y usuario aduanero en Colombia. En Andrés Aucejo et al., Alternative Dispute Resolution en Derecho Tributario Comparado, cit., pp. 163 ss. 
opción de prescindir del recurso en vía administrativa y acudir de manera directa ante la jurisdicción contencioso administrativa" ${ }^{70}$.

5. PROPUESTAS DE MODELOS COMPARADOS DE RESOLUCIÓN ALTERNATIVA DE CONFLICTOS EN MATERIA TRIBUTARIA SUSCEPTIBLES DE APLICACIÓN EN ESPAÑA Y EN LATINOAMÉRICA

En este apartado propondré una serie de institutos tributarios cuya característica común es la de constituir sistemas que tienden a evitar la lite tributaria, actuables en distintos momentos. Incluyo por tanto los distintos institutos que se pueden utilizar:

- En un momento previo al procedimiento administrativo, evitando así los conflictos (consultas, revocación, etc.).

- Durante el procedimiento administrativo (fases de gestión y liquidación del tributo).

- Sistemas aplicables en revisión administrativa.

- Sistemas de resolución alternativa de conflictos actuables en vía jurisdiccional.

Nota: bien entendido que hay algunos de estos institutos que se pueden plantear en cualquiera de estas fases.

a) Fase previa: sistemas que evitan el litigio Métodos deflactivos como: revocación, "taxpayer advocate" y consultas

b) Fase administrativa tributaria Soluciones convencionales de (gestión, liquidación, inspección, terminación del procedimiento)

c) Fase de revisión administrativa Mediación/ arbitraje y otros ADR

d) Fase jurisidiccional La conciliación tributaria

\subsection{Modelo de mediación tributaria susceptible de aplicarse}

en Latinoamérica inspirado en el derecho comparado ${ }^{71}$ :

Estados Unidos, Italia ${ }^{72}$ y Reino Unido

De manera similar a los sistemas de derecho comparado, en particular, al modelo norteamericano y también del Reino Unido e italiano, podría arbitrarse un modelo de mediación tributaria para España y Latinoamérica que tenga en cuenta las siguientes coordenadas:

70 Londoño GutiérRez, F., Modelo de jurisdicción tributaria en Colombia. En Andrés Aucejo et al., Alternative Dispute Resolution en Derecho Tributario Comparado, cit., pp. 341 ss.

71 Véase ANDRÉs AuceJo, Acuerdos y otras técnicas transaccionales en el ordenamiento tributario nacional y en derecho tributario comparado. Una propuesta sobre Mediación y Agencia Tributaria Catalana, cit., pp. 367 ss.

72 Sobre el modelo de mediación tributaria en España véase ANDRÉs AucEJo, Reclamo e mediazione tributaria nel Diritto tributario italiano. ¿Para cuándo en España?, cit. 
Ámbito objetivo de aplicación: la mediación debería poder aplicarse con carácter general en relación con las cuestiones suscitadas con ocasión de la aplicación y recaudación de impuestos estatales, regionales y locales que en su caso existan en los distintos países.

Materias objeto de mediación: en consecuencia con el ámbito de aplicación de la mediación, el objeto de la mediación podría suscitarse tanto sobre cuestiones de hecho como sobre calificaciones jurídicas, siendo el director de la Agencia Tributaria de Cataluña competente para concretar las materias específicas.

Ámbito de aplicación subjetivo: se podrá instar la solicitud de mediación tanto de oficio como por el contribuyente, bajo las siguientes pautas ${ }^{73}$ :

El instituto de la mediación tributaria debe construirse - en línea con lo establecido en Italia a efectos de la aplicación de los mecanismos alternativos de resolución de conflictos tributarios- pensando en un nuevo escenario en el que debe prevalecer la transparencia administrativa asentada en un ambiente presidido por un renovado espíritu de interrelaciones fisco-contribuyente ${ }^{74}$. La actividad administrativa, como se ha dicho, no puede ser ejercitada según un esquema rígido preordenado pues requiere cierto grado de discrecionalidad ${ }^{75}$ que debe derivar de una adecuada profesionalidad y un sólido sentido de la responsabilidad ${ }^{76}$. El problema, como podrá intuirse, es conocer el límite de tales competencias administrativas, debiendo conciliarse tal potestad con un sistema que garantice el principio de capacidad contributiva del contribuyente ${ }^{77}$, toda vez que el principio de reserva de ley constitucionalmente reconocido ${ }^{78}$.

73 Véase AndRÉs AuceJo, Mecanismos convencionales y transaccionales. En Quincena Fiscal, n. ${ }^{\circ} 21,2010$,pp. 25 ss.

74 Véase Patrizi, G. y Ferrara, G., La definizione degli imponibli in contraddittorio e l'Amministrazione finanziaria, Il Fisco, 1999, pp. 6488; en parecido sentido, Consolazio, M. L., L'accertamento con adesione del contribuente. En Rass. Tributaria, 1997, p. 67; y STIPO, M., L'accertamento con adesione del contribuente, cit., p. 1251.

75 En el bien entendido de que, más que de discrecionalidad administrativa, en sentido riguroso habría que hablar de discrecionalidad técnica-valorativa. Véase sobre el particular STIPO, M., L'accertamento con adesione del contribuente ex D. legs. 19 giugno 1997, n. 218, nel quadro generale delle obbligazioni di diritto pubblico e il problema della natura giuridica, Rassegna tributaria, n. ${ }^{\circ}$ 5/1998, pp. 1256-1257. En general, sobre discrecionalidad administrativa, véase Cassese, S., Trattato di diritto amministrativo, Diritto amministrativo generale, t. I, Milano, 2000, pp. 691 ss., y, en el ámbito tributario, entre otros, Moscatelli, M. T., Discrezionalità dell' accertamento tributario e tutela del contribuente, Rassegna tributaria, 1997, pp. 1107 ss.

76 Gianzuzzi, C., Gli strumenti deflattivi del contenzioso. En La finanza locale, cit., p. 421.

77 Marello, L'accertamento con adesione, cit., pp. 20-21; Grassi, E., La partecipazione del contribuente al procedimento tributario nell'accertamento con adesione, Diritto e pratica tributaria, 1998, p. 1506.

78 Sobre el particular véase, de Fedele, A.: Rapporti tra nuovi metodi di accertamento e principio di legalità. En Rivista di diritto tributario, 1995, fasc. 3, marzo, pp. 241-246; Commento all'art. 23 Cost. Commentario alla Costituzione, G. Branca (al cuidado de), Bologna-Roma, 1978, y La riserva di legge. En Trattato di diritto tributario, Amatucci (dir.), Padova, 1994, I, pp. 157 ss. 
Por tanto, si bien es cierto que el ámbito subjetivo de aplicación está presidido por el principio de voluntariedad para las partes (contribuyentes y Administración), respecto a esta última debiera entenderse como un poder-deber siempre que exista causa. De esta suerte, para que la mediación sea efectiva sería necesario que los Órganos superiores de la AEAT manifestaran una aptitud proclive (expresa y tácitamente) hacia su utilización pues, en otro caso, la implantación de iure del instituto de la mediación tributaria caerá en el olvido y desuso como así parecen haber caído las actas con acuerdo del contribuyente, consecuencia -a juicio de quien suscribe- de una clara ausencia de voluntad política hacia su utilización ${ }^{79}$.

Autoridad: el procedimiento de mediación se llevará a cabo por mediadores que deberán ser imparciales, inamovibles, seleccionados de forma pública y objetiva, cualificados en derecho tributario y que en todo caso deberán poseer formación en mediación.

El procedimiento de mediación sería susceptible de llevarse a cabo por los siguientes cauces ${ }^{80}$ :

A) Que se cree un servicio u oficina de mediación, tal y como sucede en Estados Unidos $^{81}$, que podría pertenecer al propio órgano encargado de dictar el acto administrativo, pero que estuviera separado completamente del órgano que conoce del caso. Por ejemplo, que se cree un servicio de mediación dentro de la propia

79 En Italia, tengo certera constancia, tardaron algunos años para que los inspectores de hacienda aplicasen en la práctica el instituto de la revocación de los actos tributarios desfavorables para el contribuyente. Era tanto como admitir el error del inspector actuario. Años después se observa un uso corriente de esta figura. A su utilización sin duda contribuyó la posibilidad de imputación en costas a la Administración tributaria. y respecto a otros institutos de resolución alternativa de conflictos como las liquidaciones con acuerdo del contribuyente, hoy de uso corriente en Italia, debe en gran parte su éxito, a que el criterio que desde los altos cargos de la Agenzia delle Entrate sobre todo, y del Ministero delle Finanze, se hizo llegar a los inspectores actuarios a través de circulares, instrucciones internas y cursos de formación, fue la potenciación y uso habitual de los mismos. Durante los años 2002 y 2003 tuve ocasión de vivir este proceso y mantener conversaciones con altos cargos de la Agenzia delle Entrate así como del Ministero delle Finanze. Por ejemplo, para la Región del Lazio, desde la propia Sede Central del Accertamento con adesione se impulsa y fomenta su uso, lo que se traduce en que en todos los uffici unici de esta Región, cuando el contribuyente llega a una delegación de Hacienda, se le presta toda la ayuda y voluntad para que pueda alcanzarse un acuerdo sobre la liquidación. Por aportar alguna cifra real, en el año 2003, p. ej., en la Delegación de Hacienda de la vía Ippolito Nievo, el 50\% de las liquidaciones de IRPF que el contribuyente recibía se saldaban con acuerdo en dicha oficina. Sobre estos aspectos, véase, de ANDRÉs AUCEJo, Los instrumentos deflactivos del contencioso tributario en Italia. En especial "L'accertamento con adesione". Análisis cualitativo y cuantitativo, cit., y La resolución alternativa de conflictos tributarios en Italia, Marcial Pons, 2008.

80 Citados en Andrés Aucejo, E., Mecanismos convencionales y transaccionales. En Quincena Fiscal, n..$^{\circ}$ 21, 2010, pp. 27 yss.; y véase ANDRÉs AucEJo, Acuerdos y otras técnicas transaccionales en el ordenamiento tributario nacional y en derecho tributario comparado. Una propuesta sobre Mediación y Agencia Tributaria Catalana, cit.

81 En Estados Unidos, la Oficina de Apelaciones es un servicio del IRs pero separado e independiente de la oficina o delegación que conoce del caso que se recurre. 
Agencia Tributaria o bien dentro de la Agencia Tributaria autonómica, con independencia funcional y orgánica. En estos casos podría pensarse en un cuerpo de mediadores de la Agencia Tributaria de que se trate, a cuyo fin se deberían superar unas pruebas teóricas y prácticas y el curso selectivo de formación en mediación exigido en la convocatoria pública pertinente. Entre las bases del concurso oposición deberán establecerse el régimen de incompatibilidades, causas de exclusión y abstención, y también disposiciones transitorias sobre homologaciones y formación complementaria, en su caso.

Esta oficina podría ejercitar la mediación tanto en el supuesto de que ya se haya dictado el oportuno acto administrativo susceptible de impugnación en vía de revisión como en los supuestos comentados en que todavía no se haya dictado la liquidación administrativa.

B) Que se haga uso de los mediadores nombrados con arreglo a la legislación reguladora de la mediación en derecho privado, en cuyo caso, necesariamente, el mediador deberá ser experto en materia tributaria para poder ejercer en temas de esta índole ${ }^{82}$.

C) Otra alternativa podría ser la designación conjunta del mediador por parte de la Administración y de los administrados ${ }^{83}$.

Proceso de mediación tributaria

Carácter: la mediación tiene naturaleza voluntaria para las partes.

Momento: la solicitud de mediación podrá presentarse por el contribuyente o por la Administración una vez la Agencia Tributaria de Cataluña haya dictado el acto administrativo tributario en ejercicio de su potestad tributaria y con carácter previo y potestativo a la reclamación económico administrativa.

Lugar: la instancia se presentará ante la propia sede de la Agencia Tributaria de Cataluña.

Forma: la solicitud de mediación se presentará por escrito en papel o telemáticamente, a cuyo fin puede seguirse un modelo a tal efecto previsto en la ATC y dirigida al director de dicha Agencia.

Revisión de la solicitud: corresponde al director de la Agencia Tributaria de Cataluña aprobar o negar una solicitud de mediación tributaria. Podrá requerir el asesoramiento de la Junta de Gobierno ${ }^{84}$.

82 En esta línea se quiso conseguir -a efectos del arbitraje tributario, pero sin éxito- que existiera un registro de Hacienda de mediadores independientes (Informe para la reforma de la $L G T, 2001$, cit.).

83 Así Lauroba, E., El iter procedimental de la mediación. En Andrés Aucejo et al., Alternative Dispute Resolution en Derecho Tributario Comparado y su aplicación en la Administración tributaria de Cataluña, cit., pp. 357 ss.

84 Podría pensarse en asesoramiento por parte del Comité ejecutivo (formato por las cabezas de área y delegados territoriales), órgano que ejerce, entre otras, funciones de asesora- 
- Si se aprueba la solicitud: el director informará al contribuyente y al jefe del equipo que llevó el caso (de la escala de inspección o de la escala técnica).

- Si se rechaza la solicitud: no cabe apelación pero el contribuyente puede solicitar una entrevista con el director para que le explique los motivos, que en todo caso habrán de estar motivados.

Plazos: sería conveniente que el proceso de mediación no se prolongase por un período superior a dos o tres meses en su conjunto. Tiempo durante el cual quedaría suspendido el plazo para impugnar en vía económico-administrativa (ante la Junta de Finanzas o ante el TEAR).

Efectos: con carácter general, el acuerdo alcanzado en mediación no será impugnable por ninguna de las partes. El contenido del acuerdo/s firmado/s por las partes sólo podrá ser objeto de impugnación o revisión en vía administrativa por el procedimiento de declaración de nulidad de pleno derecho previsto en el artículo 217 LGT, sin perjuicio del recurso que pueda proceder en vía contencioso administrativa por la existencia de vicios en el consentimiento.

Protocolo de Acuerdo de mediación tributaria de la Agencia Tributaria de Cataluña ${ }^{86}$

Si se hubiera aceptado la solicitud de mediación, el director de la Agencia Tributaria de Cataluña o persona en quien delegue convocará a las partes a una entrevista en la cual se compila el modelo de acuerdo de mediación. Dicho modelo consiste en un documento marco en el que constan una serie de aspectos:

1. Identificación de las partes e información mínima sobre el procedimiento de mediación (el mediador actuará asistiendo a las partes para definir las cuestiones y promover el acuerdo).

2. Naturaleza del proceso. Participación y renuncia:

- El procedimiento es optativo.

- Las partes pueden asistir a la sesión con representantes (abogado, asesor fiscal, ...) ${ }^{87}$.

- Cualquiera de las partes puede renunciar al procedimiento antes de alcanzar el acuerdo/s.

3. Cuestiones objeto de mediación. Se indica el período impositivo e impuestos a los que afecta, así como las cuestiones objeto de mediación.

4. Lugar de mediación. La mediación tendrá lugar en las oficinas de la ATC.

5. Propuesta de calendario:

- Se determina el año, mes, día y hora de la sesión de mediación. Podrá celebrarse más de una sesión de mediación.

- Presentación de materiales. Como mínimo dos semanas antes de la fecha de la sesión de mediación se deberá remitir al mediador la documentación.

miento al director de la ATC; sin embargo, por motivos de neutralidad quizás sería más oportuno que tal función la ejerciera la Junta de Gobierno de la ATC.

85 Inspirado en el modelo de acuerdo de mediación norteamericano (Revenue Procedure 2009-44).

86 En el modelo de acuerdo de mediación norteamericano dos semanas antes de la mediación, como máximo, cada parte deberá entregar a la otra parte y al mediador una lista de representantes que asistirán a la sesión de mediación, designado a la persona que tiene capacidad de decisión. 
Cada parte deberá presentar al mediador un escrito no superior a 20 páginas sobre cada tema. El mediador puede solicitar información adicional antes de la sesión de mediación si se considera necesario para una completa comprensión de los temas objeto de mediación. 6. Confidencialidad: el proceso de mediación será confidencial. Los empleados de la ATC y todos los que participen están sujetos a confidencialidad. 7. Neutralidad: están prohibidos los contactos de las partes con el mediador fuera de la sesión de mediación. 8. Actas de mediación: al término de la sesión/es de mediación el mediador levantará acta designando los elementos y circunstancias relevantes en relación al impuesto debido y en su caso intereses y sanciones. En el caso de que dichas actas se firmen por las partes los acuerdos parciales adoptados tendrán la misma validez jurídica que el acuerdo final alcanzado en mediación (en relación a las materias que hayan sido objeto de acuerdo). 9. Informe del mediador: al finalizar la sesión de mediación el mediador prepara un informe breve y por escrito presentando una copia a cada parte. Dicho informe deberá estar motivado con indicación de los elementos y circunstancias concurrentes que conducen a la adopción del criterio seguido. Deberá contener el impuesto debido y en su caso, intereses y sanciones ${ }^{88}$.

10. Acuerdo de mediación: si las partes están de acuerdo firmarán el informe del mediador. Si no hubiera acuerdo el contribuyente podrá recurrir en vía administrativa el acto administrativo tributario de la ATC de que se trate.

11. Validez jurídica del acuerdo alcanzado en mediación: Efectos. Alcanzado un acuerdo y suscrito por las partes no podrá ser objeto de impugnación. El contenido del acuerdo/s firmados por las partes sólo podrá ser objeto de impugnación o revisión en vía administrativa por el procedimiento de declaración de nulidad de pleno Derecho previsto en el artículo 217 LGT, sin perjuicio del recurso que pueda proceder en vía contencioso-administrativa por la existencia de vicios en el consentimiento.

\subsection{Sobre la necesidad de legislar sistemas de ADR}

Uno de los principales paradigmas del mundo en técnicas de ADR en materia tributaria es sin duda Estados Unidos. Allí se ha ido ensanchando el conjunto de sistemas de ADR de manera que el contribuyente pueda llegar a un acuerdo con la Administración, como sigue: Mediation, Fast Track Mediation, Arbitration, Fast Track Settlemen, Early referral. Amén de que si tampoco se llega a un acuerdo el contribuyente puede ir a la Office Appeals u oficina de apelaciones antes de entablar un recurso en vía jurisdiccional.

Es importante remarcar a la atención que -análogamente a lo que sucede en todos los países citados- el contribuyente debería tener derecho necesariamente a, una vez se suscita el conflicto con la Administración, poder optar bien por los sistemas de ADR o bien ir a los tribunales de justicia.

Debería instaurarse un paquete de sistemas de ADR que el contribuyente pudiera activar en su caso, como sucede por ejemplo, en:

87 En virtud del artículo 5 de la Ley 7/2007, de 17 de julio de la ATC, amén de las funciones de aplicación de los tributos, también la potestad sancionadora atribuida a la ATCA se rige por la LGT y normativa de desarrollo, etc. 
- Australia, donde desde los años 1990 se han promovido sistemáticamente los procedimientos alternativos de resolución de conflictos en derecho administrativo y tributario (Facilitative processes, Advisory processes, Determinative processes, Blended dispute resolution processes).

- Reino Unido, donde desde 2013 hay dos programas estables: para grandes empresas y para el resto de contribuyentes. En estos proyectos hay tres tipos de modalidades de ADR: Facilitated discussion, Facilitate mediation, Evaluate mediation.

- Holanda, donde desde el año 2001 se cuenta con un sistema de mediación administrativa, el cual se puede incardinar en cualquier fase del procedimiento administrativo o judicial, llevándose a cabo por empleados de la propia Administratición tributaria.

- Bélgica, donde en el año 2007 se crea un sistema de conciliación fiscal (que se aplica desde el año 2010) que representa una forma híbrida entre lo que sería una oficina de defensa del contribuyente y un servicio de ADR.

- Italia, desde el año 2010 se ha establecido la mediación obligatoria tributaria para actos de cuantía menor o igual a 20.000 euros, debido a que el $85 \%$ del contencioso tributario está generado por deudas que no superan dicha cuantía.

- Sería muy importante que los ministerios de los distintos países o quien corresponda analizara minuciosamente los datos estadísticos -que ellos sí tienen- para conocer cuestiones tan importantes como: quién genera la litigiosidad: gestión, inspección, recaudación, en qué porcentaje; cuál es la cuantía de las reclamaciones, cuánto se estima y desestima en tribunales según el órgano de origen. Sin duda las cifras estadísticas de estas y otras cuestiones serían un importante elemento en la toma de decisiones para acabar con la litigiosidad. Si no sabemos ni quién genera más litigiosidad, ni cuáles son las cuantías de las reclamaciones, ni de qué órganos proceden, ¿cómo vamos a tomar medidas correctas para reducir la litigiosidad?

Y en esa línea, lo primero que tendrían que analizar es la cuantía de las reclamaciones, pues mucho nos tememos que en España (ya que tenemos datos oficiosos de inspección nacional tributaria) el $80 \%$ de las reclamaciones que llegan a los TEARs de la Agencia (inspección tributaria) son por deudas inferiores a los 6.000 euros. En Italia para deudas inferiores a 20.000 euros hay que ir obligatoriamente a la mediación tributaria antes de ir a la jurisdicción tributaria (commissioni tributarie), esto porque un $80 \%$ de los litigios tienen un importe inferior a dicha cifra ${ }^{88}$.

Estos y otros son datos fundamentales. Si ello es así, e incluso aunque no fuera tan acusado, se podrían arbitrar sistemas de ADR específicos para pequeños casos y específicos para grandes empresas, como sucede en Estados Unidos 
o en el Reino Unido, de manera que se limpiara el escenario de expedientes de pequeña monta y otras causas susceptibles de impugnar en los tribunales económico-administrativos. Se ganaría en celeridad, disminución de costes, justicia tributaria y, sobre todo, se dejaría la tutela judicial efectiva para los casos que requieren de ella. Pues el recurso a los tribunales de justicia en ningún caso puede ser eliminado.

\subsection{Las consultas a la Administración}

De nuevo, el modelo norteamericano resulta de gran interés también en este campo $^{89}$. Las denominadas Revenue ruling consisten en respuestas de la Administración a consultas formuladas por contribuyentes, pero que, por su gran interés y peso específico, se convierten en normas que se aplican por la generalidad de los contribuyentes siendo seguidas tanto por la Administración como por los administrados. Contienen normas de interpretación sobre cuestiones sustantivas o materiales de derecho tributario.

También existen las private ruling, cuya aplicación, a diferencia del caso anterior, no se hace extensiva al resto de contribuyentes.

La gran seguridad que proporcionan dichas consultas evita mucha litigiosidad.

Por su parte, en el ordenamiento chileno también el instituto de la consulta tributaria tiene una gran raigambre legal, administrativa y doctrina $l^{90}$. Según ese autor, "la interpretación administrativa sustentada por el Director, en todo caso, tiene una importancia vital en la práctica tributaria". Dichas consultas producen efectos vinculantes para la propia Administración tributaria, en general, y para los funcionarios del servicio, en particular. Pero no posee tal efecto para los tribunales de justicia. El consultante tampoco resulta obligado por la respuesta, pero si se acoge a ella quedará a salvo de un cobro retroactivo de impuestos, frente a un cambio de criterio por la Administración.

Resulta también interesante el sistema francés, en tanto que, en relación con la respuesta de la Administración fiscal a una consulta del contribuyente sobre la interpretación de un texto fiscal o sobre la calificación de una situación concreta (rescrit fiscal), "para que produzca efectos preclusivos se exige que la respuesta suponga la adopción de una postura clara y precisa respecto del sentido y las consecuencias del texto legal tributario. El texto emanado de la

89 Véase sobre el particular, AndRÉs AuCEJo, E., Las consultas tributarias en Estados Unidos. En Andrés Aucejo et al., Alternative Dispute Resolution en Derecho Tributario Comparado y su aplicación en la Administración tributaria de Cataluña, cit., pp. 220 ss.

90 Montecinos, J., El régimen de la consulta tributaria en Chile. En Andrés Aucejo et al., Alternative Dispute Resolution en Derecho Tributario Comparado, cit., pp. 46 ss. 
administración pública ha de precisar el contenido de las disposiciones legales o reglamentarias aplicables sobre una determinada materia en particular" ${ }^{\prime 1}$.

\subsection{La revocación de los actos administrativos tributarios contrarios al contribuyente}

La Ley 58/2003, Ley General Tributaria española (LGT), introdujo la figura de la revocación en derecho tributario. Sin embargo, tal y como me he pronunciado en distintas publicaciones, considero que se trata de una regulación "exigua o tímida", por las razones que a continuación apunto ${ }^{92}$.

Modelo italiano: considero más adecuado el modelo italiano de revocación de los actos tributarios denominado Autotutela della amministrazione finanziaria, con base en los siguientes argumentos:

1. En la LGT los motivos para retirar el acto se constriñen a determinadas causas tasadas ${ }^{93}$, a diferencia de la regulación italiana que comprende tanto "l'annulamento" o posibilidad de retirar los actos administrativos tributarios por motivos de legalidad (error de derecho) o por falta de fundamento (error de hecho), como también la "revoca", que permite retirar el acto por motivos de "oportunidad" in genere ${ }^{94}$. Así consideramos muy acertado el régimen italiano en tanto que abarca también el supuesto de anular un acto por motivos de economicidad (p. ej., para recaudar una cantidad ínfima se gastan en trámites administrativos y de gestión importes muy superiores), o bien el caso de que la jurisprudencia sigue una línea contraria al sentir de la Administración tributaria, etc. Esta es también la regulación jurídica establecida en el sistema tributario chileno con aplicación en la esfera tributaria, donde como afirma Contipelli, un ejemplo de revocación ocurre cuando los medios empleados por la Administración pública para promover la cobranza del tributo son más costosos a los cofres públicos que el propio valor que es exigido. Tal hipótesis configura un criterio de proporcionalidad de la tributación compatibilizada con la idea de eficiencia e incluso de probidad administrativa (art. $8 .^{\circ}$ ), orientaciones constitucionales que deben permear la política fiscal ${ }^{95}$.

91 Véase Tovillas, J., El sistema de Restrit fiscal francés. En Andrés Aucejo et al., Alternative Dispute Resolution en Derecho Tributario Comparado, cit., pp. 61 ss.

92 ANDRÉs Aucejo, La resolución alternativa de conflictos tributarios en Italia, cit.

93 Actos que infrinjan manifiestamente la ley; circunstancias sobrevenidas; indefensión de los interesados durante la tramitación del procedimiento.

94 Sobre estos particulares véase AndRÉs Aucejo, La revocación de oficio de los actos administrativos: retos para su adopción en la legislación tributaria española y su regulación jurídica en Italia, cit., pp. 281-318.

95 Contipelli, E., La revocación de los actos administrativos tributarios en Chile. En Andrés Aucejo et al., Alternative Dispute Resolution en Derecho Tributario Comparado, cit., pp. 137 ss. 
2. Además nótese que en Italia la propia ley que crea el instituto de la "autotutela tributaria" prevé la posibilidad de retirar de oficio el acto ilegítimo, infundado o inoportuno, también en caso de pendencia de juicio y de no impugnabilidad (actos firmes), siempre que no exista sentencia judicial firme de mérito o fondo. El artículo 219.2 LGT establece que la revocación sólo será posible mientras no haya transcurrido el plazo de prescripción.

Modelo alemán: por lo que respecta a otros sistemas de revisión administrativa, considero muy oportuno el modelo alemán del recurso extrajudicial en vía administrativa ante el mismo órgano que dictó el acto: Einspruch. En la práctica funciona como una auténtica revocación, de manera que si el contribuyente no está de acuerdo con la liquidación inmediatamente acudirá a la Administración y de forma gratuita y libre pedirá que se revise el acto. La Administración deberá revisar completamente el expediente, y si ve que se ha equivocado, proceder directamente a su modificación sin que resulte necesaria una resolución formal del recurso presentado ${ }^{96}$. Mediante este procedimiento se persiguen los siguientes fines: - tutelar la posición jurídica del contribuyente, en primer lugar; - controlar la actuación de la propia Administración; - finalmente, constituye un filtro para impedir o evitar que un gran número de causas lleguen a los tribunales.

\subsection{The taxpayers' advocate}

En relación a la figura del Defensor del Contribuyente desde luego un modelo a imitar podría ser el norteamericano ${ }^{97}$. En él, el Defensor del Contribuyente, amén de sus funciones propias de órgano que aglutina y resuelve las quejas del contribuyente, tiene como función el estudio, análisis y presentación de propuestas de reformas normativas o de pautas de actuación en la aplicación del sistema tributario que contribuyan a mejorar su eficiencia reduciendo, al mismo tiempo, la presión fiscal indirecta del contribuyente. De esta manera las quejas "no caen en saco roto" sino que constituyen una especie de feedback o retroalimentación del sistema mejorando su eficacia y disminuyendo la litigiosidad.

\subsection{Los acuerdos en vía administrativa tributaria}

En materia de acuerdos en vía administrativa tributaria, sin duda es un modelo de extraordinario relieve el sistema de Alemania. País en el que, si bien no están legislados los acuerdos en vía administrativa, la gran reducción de la litigiosidad por virtud de estos hizo que se consolidaran en la práctica de los

96 Ver su desarrollo en EHMCKE y Marín-BARnUevo FABo, La revisión e impugnación, cit.

97 Andrés Aucejo y Rozas Valdés, El Defensor del Contribuyente en Italia y Estados Unidos, cit. 
hechos y también jurisprudencialmente. Precisamente las principales objeciones manifestadas en contra de la positivización de las transacciones en el ordenamiento financiero han provenido del emblemático principio de legalidad reconocido en el § 85 de la Ordenanza Tributaria Alemana. Así, concluida la actuación inspectora se realiza la famosa "entrevista final", en la cual se discuten todos los aspectos controvertidos para alcanzar el acuerdo final:

Acerca del resultado de la inspección deberá mantenerse una entrevista (entrevista final) a menos que de acuerdo con dicho resultado no se produzca ninguna modificación en los fundamentos de la imposición o el obligado tributario renuncie a la entrevista. En la entrevista final se discutirán especialmente los hechos controvertidos, así como la calificación jurídica de los datos comprobados en la inspección y sus consecuencias tributarias $(\S 201 \mathrm{OA})^{98}$.

Este es precisamente el escenario que presenta el sistema chileno, donde, pese a no estar consagrados los acuerdos en vía administrativa en el sistema tributario, "la Administración tributaria se ha valido de las posibilidades de la ley para configurar instancias administrativas de intercambio de información y acuerdo, incluso conciliación, con los contribuyentes"99.

Modelo italiano. En Italia desde la segunda mitad de los años 1990 se legisló el instituto del "Accertamento con adesione del contribuente", que constituye un sistema para llevar a cabo un acuerdo con la Administración tributaria en vía administrativa tanto sobre cuestiones de hecho como de derecho. De alcanzarse el acuerdo, siempre sobre materias disponibles en derecho tributario, se deberá pagar en el plazo de veinte días, llevando aparejada una disminución del importe de las sanciones, en el caso de que estas existan.

En España, en el año 2003 se introdujeron en la LGT las denominadas "actas con acuerdo", sin embargo, una de las principales críticas que he formulado desde hace años al respecto ha sido que se trata de una regulación tímida porque, a mi juicio, los acuerdos entre la Administración tributaria y el contribuyente deberían poderse llevar a cabo tanto antes de la liquidación administrativa (previsto en el supuesto de nuestras actas con acuerdo) como, lo que es muy importante, una vez notificada la misma ${ }^{100}$. Por contra, el modelo adoptado en España para llegar a un acuerdo entre la Administración y el contribuyente se diseña para que tenga lugar con carácter previo a la liquidación.

98 Martín Lobenhofer y García Frías, Resolución alternativa, cit.

99 Masbernat, P., Acuerdos en via administrativa en el sistema tributario chileno. En Andrés Aucejo et al., Alternative Dispute Resolution en Derecho Tributario Comparado y su aplicación en la Administración tributaria de Cataluña, cit., pp. 220 ss.

100 La resolución alternativa de conflictos tributarios en Italia, cit. 
De hecho, en Italia la mayoría de las liquidaciones con acuerdo del contribuyente se producen precisamente ex post con respecto a la liquidación, momento en el cual existe una mayor sensibilidad por parte del contribuyente y, casi me atrevo a decir, de la Administración para llegar al acuerdo. E igualmente en el modelo anglosajón, tanto en el sistema británico como en el norteamericano, se puede llegar a un acuerdo en cualquier momento posterior a la liquidación tributaria, que por lo general se inicia mediante una entrevista con la Administración tributaria.

Proponemos como paradigma el modelo norteamericano, en el cual, de no alcanzarse tal acuerdo, el contribuyente puede acceder a una batería de sistemas de resolución alternativa de conflictos tributarios (Mediation, Fast track mediation, Arbitration...) y/o acudir a las oficinas de apelación. O, en su caso, optar por no ir a los mecanismos de ADR y decidirse por ir directamente a la Tax Court u otro de los dos tribunales de justicia que pueden conocer de materias tributarias, en el entendido de que en estos casos no cabrá imputación en costas a la Administración tributaria.

\section{LA CONVENIENCIA LAS TÉCNICAS TRANSACCIONALES \\ EN VÍA DE LA JURISDICCIÓN CONTENCIOSO ADMINISTRATIVA}

En la Ley de la Jurisdicción Contencioso Administrativa española se establece la posibilidad de que el juez, "potestativamente", pueda someter a las partes la posibilidad de llegar a un acuerdo (art. $77 \mathrm{LJCA})^{101}$.

Sin embargo, con motivo del proceso de reforma de la Ley 60/2003, de 23 de diciembre, de Arbitraje y de Regulación del Arbitraje Institucional en la Administración General del Estado, se modificó la redacción de este artículo 77 LJCA, estableciendo la obligatoriedad para el juez de proceder a la realización de acuerdos o transacciones entre las partes (es el sistema vigente actualmente en Italia tanto en derecho civil como tributario). Dicha redacción, infortunadamente, no fue aprobada, no habiendo cambiado en este punto la redacción de la LJCA.

Dicho proceso de reforma reabrió el debate sobre la conveniencia de las técnicas alternativas para la resolución de conflictos en vía contenciosa ${ }^{102}$, sobre todo en el derecho público y particularmente en derecho tributario.

101 Art. 77 LJCA: "1. En los procedimientos en primera o única instancia, el Juez o Tribunal, de oficio o a solicitud de parte, una vez formuladas la demanda y la contestación, podrá someter a la consideración de las partes el reconocimiento de hechos o documentos, así como la posibilidad de alcanzar un acuerdo que ponga fin a la controversia, cuando el juicio se promueva sobre materias susceptibles de transacción y, en particular, cuando verse sobre estimación de cantidad".

102 Hurtado IgLesias, S., Mediación y arbitraje, medios alternativos para mejorar nuestros sistema de justicia, Otrosí, n. ${ }^{\circ} 3$, julio, 2010, p. 7. Al respecto véase el interesante artículo de 
Así, en el Anteproyecto para la reforma de la Ley 60/2003, de 23 de diciembre, de Arbitraje y de Regulación del Arbitraje Institucional en la Administración General del Estado (2010), se propuso la modificación del artículo 77 LJCA (D.F. 3.a); previéndose que "En los procedimientos en primera o única instancia, el Juez o Tribunal, de oficio o a solicitud de parte, una vez formuladas la demanda y la contestación, someterá a la consideración de las partes el reconocimiento de hechos o documentos, así como la posibilidad de alcanzar un acuerdo que ponga fin a la controversia, cuando el juicio se promueva sobe materias susceptibles de transacción y, en particular, cuando verse sobre estimación de cantidad".

En calidad de miembro de la Comisión del Ilustre Colegio de Abogados de Barcelona para el estudio del Anteproyecto de Ley de Reforma de la Ley 60/2003, de 23 de diciembre, de Arbitraje y de Regulación del Arbitraje Institucional en la Administración General del Estado, tuve ocasión de emitir un informe al respecto manifestando que la dicha modificación cabía considerarla de oportuna y conveniente atendiendo a las siguientes razones:

a. El hecho de que se tipificara la "obligatoriedad" de que el juez o tribunal sometieran a las partes la posibilidad de un acuerdo transaccional (versus la facultad potestativa prevista en la versión de la Ley 29/1998, donde se establece que el juez o tribunal "podrá someter" a las partes la posibilidad de alcanzar un acuerdo).

b. El Anteproyecto somete al acuerdo de las partes necesariamente en los siguientes supuestos: cuando el juicio se promueva sobre materias susceptibles de transacción y, en particular, cuando verse sobre estimación de cantidad.

Nota: en España, el Informe para la Reforma de la Ley General Tributaria de 2001 (IEF, Ministerio de Hacienda) posibilita en todo caso el arbitraje ante situaciones que, si bien afectan fundamentalmente a los hechos, deben afrontarse también en otros casos en los que la distinción hecho-derecho no es tan sencilla. A título de ejemplo, se apuntan las siguientes: - cuando se aplique una presunción; - cuando se aplique un concepto jurídico indeterminado, tal como el valor de mercado; - en los supuestos de estimación indirecta; - en los casos de aplicación de los artículos 24 y 25 LGT cuando no se trate de simulación absoluta; - en los supuestos de operaciones vinculadas; - en la estimación objetiva; - en las valoraciones en general.

En Italia el instituto de la conciliazione giudiziale puede ser utilizado ante cualquier tipo de lite tributaria.

b. El artículo 77.1 incorpora el siguiente párrafo: "En este supuesto (cuando verse sobre estimación de cantidad) el juez o Tribunal podrá imponer a las partes el sometimiento a mediación de acuerdo con la legislación reguladora

XıoL Rios, J. A., El arbitraje y los tribunales de justicia, disponible en: http://www.clubarbitraje. com/files/docs/ponencia_xiol.pdf Consultado el 10/07/2010. 
de la mediación". De manera que se incluye con carácter potestativo para el juez o tribunal el sometimiento a mediación, con efecto arrastre de la legislación reguladora de la mediación en el derecho procesal tributario.

"El arbitraje, la conciliación y la mediación están asumiendo hoy un protagonismo impensado hace muy pocos años, tratando de habilitar cauces alternativos al tradicional proceso, que tengan eficacia bastante para conseguir solucionar conflictos". Figuras que obedecen a causas que tienen como denominador común la generalización de la litigiosidad.

Ello explica que, a partir de las conocidas ADR -Alternative Dispute Resolutionsurgidas en la década de los 70 en Estados Unidos -en el ámbito universitario primero y más tarde en el judicial- los Estados europeos -primero en el Reino Unido y más tarde, ya en la década de los 90, en el resto de Estados- vayan incorporando a sus sistemas procesales los cauces por los que pueda llegarse a una satisfacción de los intereses contrapuestos a extramuros del clásico proceso judicial. La reforma del Código procesal civil de 1995 o de la Ley inglesa que regula el procedimiento civil en abril de 1999 y, más recientemente, la posibilidad concedida, en diciembre de 1999, por la Ley Federal alemana a los distintos Estados federados para que establezcan, como requisito procesal cuyo cumplimiento determina la admisibilidad de la demanda en determinadas materias, la necesidad de un intento de conciliación previo a la demanda, constituyen manifestaciones de esa realidad [...]. Y, a no dudar, asistiremos muy pronto a la promulgación de Leyes sectoriales que irán recogiendo una aspiración que trasciende los ámbitos universitarios para erigirse en demanda social (Juan Martín Queralt).

En la línea con lo que vaticinara Martín Queralt, el "Anteproyecto de Ley de reforma de la Ley 60/2003, de 23 de diciembre, de arbitraje", potencia el instituto conciliatorio a través de su obligatoriedad e incorpora el instituto mediador en vía contencioso administrativa. Conciliación y mediación deberían constituir pues monedas de curso legal en la jurisdicción contencioso administrativa. Y sin duda la experiencia de esos u otros países algo nos puede alumbrar. En este sentido, el ordenamiento jurídico italiano incorporó por Decreto Legislativo 546/1992 de 31 de diciembre, rubricado "Disposiciones sobre el proceso tributario" (según redacción dada por Dcto. Legislativo 218 de 19 de junio de 1997), la figura de la conciliazione giudiziale, instituto de naturaleza procesal, con carácter conciliativo aplicable en la jurisdicción tributaria. Se trata de un instrumento que pretende alcanzar el punto de encuentro entre el contribuyente y la Administración financiera en orden al objeto controvertido, pero siempre en sede de proceso (primera instancia). La conciliazione giudiziale puede ser utilizada ante cualquier tipo de lite tributaria motivada por impugnación ya sea de actos administrativos de liquidación, actos de recaudación, acciones para la devolución de ingresos 
indebidos, e incluso aquellos que tengan por único objeto la exacción de sanciones tributarias ${ }^{103}$.

E igualmente, en el ordenamiento jurídico alemán "el Juez Financiero cumple un auténtico papel de mediador, o, más propiamente, de conciliador".

Cuando no se alcanza el acuerdo directamente entre Administración y contribuyente, está legalmente prevista la convocatoria, directamente por el juez financiero, de una reunión para la discusión entre Administración y contribuyente (Erörterungstermin), antes de la audiencia pública del caso, en la que los funcionarios de la sección de recursos representan a la Administración [...] El papel del juez financiero en esta reunión entre Administración y contribuyente [...] es muy activo, dirigiendo la discusión a modo de conciliador e intentando que las partes lleguen a un acuerdo. La reunión es muy informal y rápida (sobre dos horas es, en principio, el tiempo normalmente considerado en la agenda del Juez). En la reunión el juez analiza personalmente las pruebas y los documentos presentados por ambas partes, y escucha sus razones ${ }^{104}$.

No obstante ello, nótese que en materia tributaria no serían suficientes las modificaciones del artículo 77 de la Ley 29/1998, de 13 de junio, reguladora de la jurisdicción contencioso administrativa española, previstas en la disposición final tercera del Anteproyecto de Ley de Reforma de la Ley 60/2003, de 23 de diciembre, de Arbitraje y de Regulación del Arbitraje Institucional en la Administración General del Estado; bien sabido es que la situación de conflictividad tributaria tiene su origen en las instancias previas a la vía jurisidiccional, esto es, la situación de conflictividad tributaria trae causa de los conflictos acaecidos entre la Administración y los contribuyentes en la fase de aplicación de los procedimientos tributarios, arrastrados a la vía económico-administrativa tributaria y a la subsiguiente vía jurisdiccional contencioso-administrativa.

En línea con lo que yo misma estableciera en el Informe elaborado por la Comisión para el estudio y propuesta de medidas para la Reforma de la Ley General Tributaria de 2001 (nombrada por el Ministerio de Hacienda) ${ }^{105}$ : "la reducción de la actual situación de conflictividad en materia tributaria requiere la adopción de medidas en los primeros estadios en que aquélla se manifiesta

103 Sobre el ámbito objetivo, subjetivo, iter procesal (procedimiento simplificado/normal), perfeccionamiento y efectos de la conciliazione giudiziale véase ANDRÉs AucEJo, La resolución alternativa de conflictos tributarios en Italia, cit.

104 EsPEJo, Los recursos jurisdiccionales contra actos de la Administración tributaria en Alemania, cit., pp. 460 ss.

105 Informe para la reforma de la Ley General Tributaria, Comisión para el estudio y la propuesta de medidas para la reforma de la LGT, Ministerio de Hacienda, Secretaría de Estado de Hacienda, 2001. 
o exterioriza. De todos es conocida la situación en que se encuentran los órganos revisores, tanto administrativos como jurisdiccionales".

De ahí que con motivo del estudio del Anteproyecto de la Ley de Reforma de la Ley 60/2003, de 23 de diciembre, de Arbitraje y de Regulación del Arbitraje Institucional en la Administración General del Estado, dentro de la Comisión de normativa del Ilustre Colegio de Abogados de Barcelona para la Reforma de la Ley 60/1963 de Arbitraje, hayamos tenido ocasión de proponer que se modifique dicha Ley 60/2003 para que en la misma se contenga una disposición que prevea una modificación de la LGT y la LPEA, en su caso, con el fin de incluir las citadas técnicas transaccionales ${ }^{106}$, al tiempo que se incorpora una propuesta sobre mediación en derecho tributario.

Lamentablemente, parece que el cauce legislativo siguió otra senda. Así, en el Proyecto de la Ley de Reforma de la Ley 60/2003, de 23 de diciembre, de Arbitraje y de Regulación del Arbitraje Institucional en la Administración General del Estado, "cayó" la Disposición Final 3. a del Anteproyecto de la Ley de Reforma de la Ley 60/2003 que modificaba el artículo 77 LJCA no incorporándose mención alguna respecto al arbitraje en el ámbito tributario.

A. Sobre la posibilidad de establecer la mediación en vía jurisdiccional contencioso administrativa

Se trata este de un importantísimo aspecto que ha sido estudiado en el Presente Proyecto de Investigación por Tornos Más ${ }^{107}$, quien concluye que al amparo de la legislación vigente (art. 77 LJCA), donde se contiene la figura de la conciliación (de carácter potestativo para el juez), no existe cobertura legal para poder incluir la mediación en la jurisdicción contencioso administrativa dada la omisión al respecto en la LJCA.

Nos ilustra este autor con la existencia de un "Protocolo de actuación para la implantación de un proyecto de mediación en la Jurisdicción Contencioso Administrativa" elaborado por el Consejo General del Poder Judicial. Para la confección de dicho Protocolo se tuvo en cuenta la Recomendación del Consejo de Europa Rec(2001)9 que instaba a los Estados miembros a considerar vías alternativas a la resolución judicial de los asuntos, antes o durante el proceso judicial, tratándose de problemas que enfrenten a la Administración y a los ciudadanos.

106 ANDRÉs AucEJo, E., Informe sobre la necesidad de incluir técnicas transaccionales alternativas previas y coetáneas a la vía judicial en materia tributaria. En Informe de la Comisión del Ilustre Colegio de Abogados de Barcelona para el estudio del Anteproyecto de Ley de Reforma de la Ley 60/2003, de 23 de diciembre, de arbitraje y de regulación del Arbitraje Institucional en la Administración General del Estado.

107 Tornos Más, J., La mediación en las relaciones sujetas a Derecho Administrativo. En Andrés Aucejo et al., Alternative Dispute Resolution en Derecho Tributario Comparado, cit., pp. 399 ss. 
Importo aquí un resumen básico de las bases del citado Protocolo, habida cuenta de su trascendencia en el tema que nos ocupa. Desde mi punto de vista se trata de un documento muy acertado e importante:

a) Se define la mediación intrajudicial.

b) Se define el ámbito objetivo de aplicación (asuntos que se diriman en sede judicial en cualquier momento de la primera instancia de los recurso o de la ejecución de sentencia). Con exclusión en los procedimientos de protección de los derechos fundamentales.

c) El ámbito material alcanza a los supuestos en que el ordenamiento permite la transacción, supuestos en que se permite la terminación convencional (art. 88 Ley 30/92, supuestos que entren en el artículo 107,2 de la Ley 30/1992; ejercicio de potestades discrecionales de la Administración y fijación de hechos controvertidos en las potestades regladas.

d) La mediación se llevará a cabo por profesionales designados por instituciones de mediación, entidades públicas o privadas o corporaciones públicas. No pueden actuar como mediadores los secretarios judiciales. La intervención del "Magistrados, Juez, Secretario Judicial, o en su caso, el Fiscal como mediadores administrativos, únicamente podrá realizarse cuando no actúen de forma simultánea con el ejercicio de sus funciones jurisdiccionales o procesales y no tengan participación directa, mediante o inmediata en las actuaciones procesales correspondientes al litigio sobre cuyo objeto se realiza la mediación", letra F, 6 .

e) El procedimiento de mediación deberá iniciarse a instancia del Juez competente, de común acuerdo entre las partes o a petición de una de ellas

f) En principio el acuerdo de proceder a una mediación suspende el curso de las actuaciones por un plazo no superior a 60 días a contar desde la fecha de notificación de este acuerdo.

g) Si las partes llegan a un acuerdo que implique la desaparición de la controversia el Juez o Tribunal dictará auto declarando terminado el procedimiento (siempre que lo acordado no fuera manifiestamente contrario al ordenamiento jurídico ni lesivo del interés público o de terceros). El acta final reflejará los acuerdos de forma clara y comprensible. Dicho auto judicial se ejecutarán de acuerdo con lo previsto en el artículo 103 y siguientes de la LJCA.

El contenido del acuerdo de mediación también puede consistir en poner fin al pleito a través de cualquiera de los medios posibles de terminar el proceso distintos de la sentencia (renuncia, desistimiento, satisfacción extra procesal), o bien 
aunque esto no lo reconoce expresamente el Protocolo, también podría consistir en acordar el contenido de la sentencia (por ejemplo, una estimación parcial).

Sin embargo, dice el profesor Tornos, no creemos que esta mediación intrajudicial tenga éxito y que sea una alternativa eficaz a la tramitación ordinaria de los recursos contenciosos administrativos. Una vez el pleito está formalizado lo dirigen las representaciones letradas de las partes enfrentadas, y éstas no tendrán especial interés en abrir una incierta fase de mediación intrajudicial en la que un mediador externo tratará de buscar el acuerdo de las partes, el recurrente y la Administración recurrida.

En los litigios en que es parte la Administración el marco normativo de obligado cumplimiento es muy importante. La parte recurrente carece de los conocimientos necesarios sobre este marco y, por tanto, sobre el margen de su negociación. El mediador deberá ser un experto en derecho y a su vez conocedor de la materia objeto de conflicto, capaz de orientar a las partes en la búsqueda de su acuerdo.

La previsible complejidad de los temas en las negociaciones puede comportar que se demore la tramitación del recurso. Por todo ello, creemos que los letrados responsables de la tramitación del recurso aconsejarán no recurrir a esta mediación.

La conciliación intrajudicial, en la que el Juez dirige el proceso para llegar a un acuerdo, creemos que puede ser más efectiva, pero lo cierto es que hasta ahora ha fracasado, tal y como ya hemos comentado. Razón de más para desconfiar de la mediación intrajudicial ${ }^{108}$.

Aun a sabiendas del handicap manifestado por la acreditada opinión que me precede, considero que, sin duda, el apuntado por el CGPJ es el camino a seguir. Y pese a las reticencias que puedan surgir, evidentemente en gran parte por los letrados, considero importante apuntar hacia modelos más avanzados que el nuestro que sí lo han incorporado con muy buenos resultados. Así por ejemplo, en materia de ADR en vía jurisdiccional tributaria, es de nombrar, a título de ejemplo, el modelo alemán, donde de suyo el juez procede a realizar conciliaciones judiciales previas a la vista; véase el modelo holandés, donde también se permite la mediación intrajudicial; véase el modelo británico (que data de 1970) y, por supuesto, véase el modelo italiano, donde la mediación en vía jurisdiccional tributaria se estableció a través de la denominada conciliazione giudiziale y donde en derecho civil existe la obligación de interponer la mediación intrajudicial obligatoria en el contencioso civil. Adviértase que la vía de la obligatoriedad impuesta por el legislador no es baladí ni desdeñable. Vencida queda toda resistencia. 
Y por estas lides, estoy convencida, debería discurrir el futuro. Y en esa dirección deberían apuntar nuestros resultados fruto de la investigación de derecho comparado; alumbrando el quehacer de nuestros legisladores al traer modelos contemporáneos punteros en la materia; concienciando a la población de la necesidad de los sistemas de ADR habida cuenta de sus numerosas cualidades. En una frase: apostando por un uso eficiente de los recursos públicos que culmine en un sistema jurisdiccional, presidido por los principios de celeridad, eficacia y justicia.

Mientras ello llega, habremos pues de seguir aguardando con la esperanza de que algún día el legislador alce el vuelo y desee posar la vista más allá de sus estrechas fronteras contemplando el acontecer de todas las democracias occidentales avanzadas del mundo. Quizá entonces se decida a incorporar mecanismos transaccionales -creados ad hoc y con vocación de constituir institutos de curso corriente y legal- de resolución de conflictos tributarios como la mediación, la conciliación y el arbitraje tanto en la vía contencioso administrativa como en todas las instancias previas donde se manifieste la litigiosidad tributaria.

\section{BIBLIOGRAFÍA}

AA.vv. (1999). El Consell Tributari Municipal de Barcelona. Barcelona: Fundació Carles Pi i Sunyer.

Andrés Aucejo, E. y Alonso González, L. (dirs.) (2015). Alternative Dispute Resolution en derecho tributario comparado y su aplicación en la administración tributaria de Cataluña. Generalitat de Catalunya, disponible en: http://presidencia.gencat.cat/ web/.content/ambits_actuacio/desenvolupament_autogovern/nou_model_adm_tributaria/06_sistemes_solucio_conflictes_tributaris.pdf

Andrés Aucejo, E. (2002). Evaluación de la litigiosidad en el "Rapporto tributario" en Italia. Rivista di Diritto tributario internazionale (International Tax Law Review), $\mathrm{n}$. 2, pp. 244-278.

Andrés Aucejo, E. (2003). La revocación de oficio de los actos Administrativos: retos para su adopción en la legislación tributaria española y su regulación jurídica en Italia. Revista de Derecho Fiscal y de Hacienda Pública, n. ${ }^{\circ}$ 268, pp. 281-318.

Andrés AuceJo, E. (2004). L'evoluzione della litigiosità nelle "commissioni tributarie" italiane nel corso degli anni 1990-2000. Diritto e pratica tributaria, n. ${ }^{\circ} 4$.

Andrés Aucejo, E. (2008). La resolución alternativa de conflictos tributarios en Italia. Madrid: Ministerio de Economía, IEF.

Andrés Aucejo, E. (2008). Los institutos jurídicos de simplificación impositiva en la República Federal Alemana. En La tributación de la renta empresarial. Madrid: Marcial Pons. 
Andrés Aucejo, E. (2010). Desarrollo de los derechos constitucionales de los contribuyentes en el ordenamiento tributario español. En Foros y Debates, XXV Jornadas Latinoamericanas y XXXIV Colombianas de Derecho Tributario, Cartagena de Indias, pp. $557 \mathrm{ss}$

Andrés Aucejo, E. (2010). Mecanismos convencionales y transaccionales de resolución de conflictos en derecho tributario nacional y comparado. La mediación en derecho tributario: una propuesta de lege ferenda. Quincena Fiscal, n. . 21, pp. 13 ss.

Andrés Aucejo, E. (2014). Reclamo e mediazione tributaria nel Diritto tributario italiano. ¿Para cuándo en España? Quincena Fiscal, n. ${ }^{\circ} 17$.

Andrés Aucejo, E. y Alonso González, L. (dirs.) (2015). Alternative Dispute Resolution en Derecho Tributario Comparado y su aplicación en la administración tributaria de Cataluña. Generalitat de Catalunya.

Andrés Aucejo, E. y Raventós-Calvo, S. (2009). Taxpayer rights and guarantees in the Spanish legal system. En The Confédération Fiscale Européenne at 50 years, Part Two: A special focus on taxpayers rights and taxpayers charters, coord. Servaas van Thiel, Bruxelas, Confédération Fiscale Europeénne/Datev.

Andrés Aucejo, E. y Royuela Mora, V. (2003). “Análisis estadístico de la litigiosidad en los Tribunales de Justicia. Jurisdicción Contencioso-Administrativa (período 1990 2000)", Madrid, Instituto de Estudios Fiscales, Documento n. ${ }^{\circ} 16$.

Andrés Aucejo, E. y Royuela Mora, V. (2003). Análisis estadístico de las actuaciones inspectoras (Agencia Estatal de la Administración Tributaria. Periodo: 1995-2000). Revista Técnica Tributaria, n. ${ }^{\circ} 63$, pp. 17 ss.

Andrés Aucejo, E. y Royuela Mora, V. (2004). Análisis estadístico de la litigiosidad experimentada en el Tribunal Económico Administrativo Regional de Cataluña (19902000). Madrid: Instituto de Estudios Fiscales, Documento n. ${ }^{\circ} 25$.

Andrés Aucejo, E. y Royuela Mora, V. (2004). Análisis estadístico de la litigiosidad experimentada en los tribunales económico administrativos regionales, locales y en el Tribunal Económico Administrativo Central de España (1998-2002). Madrid: Instituto de Estudios Fiscales, Documento n. ${ }^{\circ} 25$ (también en $C T$, n. $\left.{ }^{\circ} 115,2005\right)$.

Andrés Aucejo, E. y Royuela Mora, V. (2005). Análisis estadístico de la litigiosidad en los Tribunales Económico Administrativos Regionales, Locales y Tribunal Económico Administrativo Central. Quinquenio: 1998-2002. Crónica Tributaria, n. ${ }^{\circ} 115,0210$ 2919; M. $12.580-1961$.

Andrés Aucejo, E. y Rozas Valdés, J. A. (2004). El Defensor del Contribuyente. Un estudio de derecho comparado: EE.Uu. e Italia. Madrid: Instituto de Estudios Fiscales, Documento n. ${ }^{\circ} 5$.

Arrieta, J. (1994). Las actas de la inspección de los tributos. Madrid: Civitas.

Arrieta, J. (1996). Finalización convencional del procedimiento tributario. Convención y arbitraje en derecho tributario. Madrid: IEF, Marcial Pons, pp. 194 ss.

Bilbao Estrada, I. (2005). Los acuerdos tendentes a la determinación de la obligación tributaria en la nueva LGT. Madrid: IEF. 
Bilbao Estrada, I. (2007). Cuestiones procedimentales en materia de actas con acuerdo a la luz del Proyecto de Reglamento general de las actuaciones y los procedimientos de gestión e inspección tributaria y otras normas tributarias. $C T$, n. ${ }^{\circ} 122$.

Calvo Ortega, R. (2001). En defensa del arbitraje tributario. CT, n. ${ }^{\circ} 100$.

Calvo Ortega, R. (2007). Los acuerdos fiscales. En Estudios en Homenaje al Profesor Pérez de Ayala. Dykinson.

Cassese, S. (2000). Trattato di diritto amministrativo, Diritto amministrativo generale, t. I. Milano.

Cayón Galiardo, A. (1996). Prólogo a Serrano Antón, F. La terminación convencional de procedimientos tributarios y otras técnicas transaccionales, AEDAF, monografías, $\mathrm{n} .^{\circ} 9$.

Consolazio, M. L. (1997). L'accertamento con adesione del contribuente. Rass. Tributaria, p. 67.

Cruz Padial, I. (1999). El arbitraje tributario: una opción de futuro en la terminación convencional de procedimientos. Carta Tributaria, n. ${ }^{\circ} 310$.

De Palma Del Teso, A. (2003). Las técnicas convencionales en los procedimientos administrativos. En Alternativas convencionales en el Derecho tributario. Madrid: Marcial Pons, pp. 15 ss.

Delgado Pacheco, A. (2005). Las actas con acuerdo en la nueva Lgt. En Aa.vv. La aplicación de los tributos en la nueva LGT. Madrid: IEF.

Department of the Treasury International Revenue Service. Publication 4167 (Rev. 7-2012). www.irs.gov

Fedele, A. (1978). Commento all'art. 23 Cost. Commentario alla Costituzione, a cargo de G. Branca. Bologna-Roma.

Fedele, A. (1994). La riserva di legge. Trattato di diritto tributario, dir. Amatucci. Padova, I, pp. 157 ss.

Fedele, A. (1995). Rapporti tra nuovi metodi di accertamento e principio di legalità. Rivista di diritto tributario, fasc. 3, marzo, pp. 241-246.

Ferreiro Lapatza, J. J. (2003). Solución convencional de conflictos en el ámbito tributario: una propuesta concreta. Quincena Fiscal, n. ${ }^{\circ}$ 9, pp. 15 ss.

García Novoa, C. (2002). Mecanismos alternativos para la resolución de controversias tributarias su introducción en el derecho español. Rivista di Diritto tributario internazionale, . $^{\circ}$ 2, pp. 164-166.

García-Herrera, C. y Herrera Molina, P. (2005). Reflexiones sobre el procedimiento y régimen jurídico de las actas con acuerdo. En La aplicación de los tributos en la nueva LGT (XLIX Semana de Estudios de Derecho Financiero). Madrid: MeH, pp. 519 ss.

García-Herrera, C. y Herrera, P. (2002). Técnicas convencionales e igualdad tributaria. $Q F,{ }^{\circ}{ }^{\circ} 14$. 
García-Ovíes, I. (2004). Capítulo vi. Procedimiento de inspección. La nueva Ley General Tributaria. Madrid: Civitas, pp. 478 ss.

Gayón Galiardo, A. (1982). La interdicción de la discrecionalidad en la gestión tributaria. $R E D F, \mathrm{n}^{\circ} 36$.

Gil CRUz, E. (2009). Las actas con acuerdo en el procedimiento inspector. Aranzadi, pp. 235 ss.

GonZÁleZ-CuÉlLAR, L. (1997). El arbitraje en derecho tributario. RCEF, n. ${ }^{\circ} 7$.

GonZÁlez-Cuéllar, L. (1997). Los procedimientos tributarios: su terminación transaccional, Madrid, Colex.

GonzÁlez-Cuéllar, L. (2007). Las actas de conformidad y las actas con acuerdo en la nueva LGT. Disponible en: http://e-archivo.uc3m.es/bitstream/handle/10016/12035/ actas_gonzalez-cuellar_2007.pdf?sequence $=1$.

Grassi, E. (1998). La partecipazione del contribuente al procedimento tributario nell'accertamento con adesione. Diritto e prat. trib., p. 1506.

Hurtado Iglesias, S. (2010). Mediación y arbitraje, medios alternativos para mejorar nuestros sistema de justicia. Otrosí, n. ${ }^{\circ} 3$, julio, p. 7.

Lobenhofer, M. y García Frías, A. (2004). Resolución alternativa de conflictos tributarios en Alemania. La aplicación práctica de los acuerdos sobre hechos. Quincena Fiscal, n. ${ }^{\circ} 6$.

Londoño Gutiérrez, F. (2006). Procedimientos alternativos de prevención y resolución de conflictos tributarios, FdI.

Martínez Muñoz, Y. (2004). Las actas con acuerdo en la nueva LGT. Madrid: MP.

Mata Sierra, T. (1998). La condonación de la deuda tributaria en el marco de los procedimientos concursales. Madrid: Civitas.

Merino Jara, I. (2006). Acerca de la “inexistente” Junta Arbitral del Concierto Económico. Jurisprudencia Tributaria, . $^{\circ} 6$.

Moscatelli, M. T. (1997). Discrezionalità dell'accertamento tributario e tutela del contribuente. Rassegna tributaria, pp. 1107 ss.

Muñoz Merino, A. (1996). Privilegios del crédito tributario. Pamplona: Aranzadi.

Navarro Egea, M. (2001). Notas sobre la conformidad del interesado con las actas de la inspección. Quincena Fiscal, n. ${ }^{\circ} 9$.

Olañeta, R. (2003). La creación de tribunales arbitrales en materia tributaria. Tributos Locales, n. $^{\circ} 32$.

Pastor Prieto, S. y Marín-Barnuevo Fabo, D. (2005). La litigiosidad tributaria: un análisis jurídico y económico. Madrid: IEF.

Patrizi, G. y Ferrara, G. (1999). La definizione degli imponibili in contraddittorio e l’Amministrazione finanziaria. Il Fisco. 
Rosembuj, T. (2000). La transacción tributaria. Atelier.

Rosembuj, T. (2004). La transacción tributaria en Francia, Bélgica e Italia. Quincena Fiscal, n. ${ }^{\circ}$, pp. 9 ss.

Sanz Díaz-Pañacios, J. (2007). Medidas fiscales con efecto reductor de la conflictividad en Francia. La transacción. Técnicas convencionales en el ámbito tributario. Atelier, pp. 49 ss.

Serrano Antón, F. (1996). La terminación convencional de procedimientos tributarios y otras técnicas transaccionales. AEDAF, monografías, n. ${ }^{\circ} 9$.

Soler Roch, M. (2005). Prólogo a Vicente-Arche Coloma, P., El arbitraje en el ordenamiento tributario español: una propuesta. Madrid: MP.

Stipo, M. (1998). L'accertamento con adesione del contribuente ex D. legs. 19 giugno 1997, n. 218, nel quadro generale delle obbligazioni di diritto pubblico e il problema della natura giuridica. Rassegna tributaria, n. ${ }^{\circ}$ 5, pp. 1256-1257.

Tornos MÁs, J. (1989). El Consell Tributari del Ayuntament de Barcelona. Documentación Administrativa, . $^{\circ} 220$.

Torsten Ehmcke y Marín-Barnuevo Fabo, D. (2003). La revisión e impugnación de los actos tributarios en derecho alemán. $C T, \mathrm{n} .^{\circ} 108$.

Utande San Juan, J. (2010). Las Juntas Arbitrales del Concierto y el Convenio como vía para la resolución de conflictos forales. Impuestos, vol. 26, n. ${ }^{\circ}$ 6, pp. 11 ss.

Varona Alabern, J. (2000). El crédito tributario en la quiebra. Valladolid: Lex Nova.

Xıol Ríos, J. A. El arbitraje y los tribunales de justicia. Disponible en: http://www.clubarbitraje.com/files/docs/ponencia_xiol.pdf (Consultado el 10/07/2010).

Zornoza Pérez, J. (1996). ¿Qué podemos aprender de las experiencias comparadas? Admisibilidad de los convenios, acuerdos y otras técnicas transaccionales en el derecho tributario español. En Convención y arbitraje en derecho tributario. Madrid: Marcial Pons. 